\title{
ESSENTIAL CHANGES IN THE COMPOSITION OF COPPER ALLOYS REVEAL TECHNOLOGICAL DIVERSITIES IN THE TRANSITION FROM THE EARLIEST IRON AGE TO THE EARLY ROMAN PERIOD IN LITHUANIA
}

\section{AUDRONĖ BLIUJIENE், ${ }^{1}$ GEDIMINAS PETRAUSKAS, ${ }^{1,2}$ JURGA BAGDZEVIČIENË, ${ }^{1,3}$ EVALDAS BABENSKAS, ${ }^{1}$ TOMAS RIMKUS ${ }^{1 *}$}

\author{
${ }^{1}$ Klaipeda University, Institute of Baltic Region History and Archaeology, Herkaus Manto St 84, LT-92294 Klaipeda, Lithuania \\ ${ }^{2}$ National Museum of Lithuania, Department of Prehistoric Archaeology Collections, Arsenalo St 1, LT-01143 Vilnius, Lithuania \\ ${ }^{3}$ Lithuanian National Museum of Art, Pranas Gudynas Centre for Restoration, Rūdninkų St 8, LT-01135 Vilnius, Lithuania
}

Keywords

Copper alloys, X-ray fluoresence spectrometry, technologies, jewellery, major places, exchange network, Earliest Iron Age, Early Roman period, Lithuania

\begin{abstract}
In the context of archaeometallurgical studies of copper alloys, it is relevant to record the essential changes in the elemental composition of copper alloys that occur during changes in technology and transitions in human history. This article presents the shift in the elemental composition of copper alloy from bronze-based alloys to brass ones during essential changes in archaeological material which happened at the turn of the Earliest Iron Age (500-1 BC) and the Early Roman period, from the 1st century $\mathrm{BC}$ to the middle of the 1st century AD. As early as the 2nd and 1 st centuries BC, in the Antique world and the Roman Empire and its provinces, brass was already starting to partly replace bronze. Even if the Earliest Iron Age is the least knowable period in Lithuanian prehistory, the few pieces of jewellery attributed to this period show the changes in the composition of the copper alloy. The territorial growth of the Late Antique world and internal contacts within the Barbaricum led to the expanding strength of commodities, including raw materials, technologies, cultural ideas and ideological attitudes. Goods and ideas spread throughout the vast barbarian lands, and eventually reached the forest zone of northeast Europe. Sudden changes during the Early Roman period were first of all connected with the development of settlement structure, and this has therefore made it possible to identify some major places of the production of artefacts and partly changed directions of exchange. All this was accompanied by the emergence of new jewellery types produced by skilled jewellers according to sophisticated techniques. These changes are clearly visible in Early Roman period Lithuanian archaeological material, including the elemental composition of copper alloys. The present article uses X-ray fluorescence (XRF) spectrometry to investigate the composition of copper alloys. Radiography was used to understand the construction of artefacts, and to assess the degree of their inner corrosion and sophisticated manufacturing techniques. Solder samples were taken from the surfaces of several finds, and were analysed by qualitative microchemical analysis.
\end{abstract}

\section{Introduction}

On the basis of published copper alloy artefacts from the Late Bronze Age to the Earliest Iron Age, we should acknowledge that there are only a small number of such finds in the east Baltic region compared to Scandinavia and the southwest edge of the Baltic Sea shore (Grigalavi-

*Corresponding author email: tomas.rimkus@ku.lt chene 1980, pp. 48-88; Luchtanas 1981; 1992, p. 68; 1998; Grigalavičienè 1986a, p. 77, Fig. 22.1-8, 17; 1992, p. 91, Fig. 11.1,3,6; 1995, pp. 172-188; Merkevičius 1986; VolkaitèKulikauskienė 1986, pp. 32-36; Merkevičius 2011; Čivilytė 2014, pp. 110-112; Podènas and Čivilytè 2019).

In the Late Bronze Age, hillforts or hilltop settlements in east and northeast Lithuania are quite contrasting 


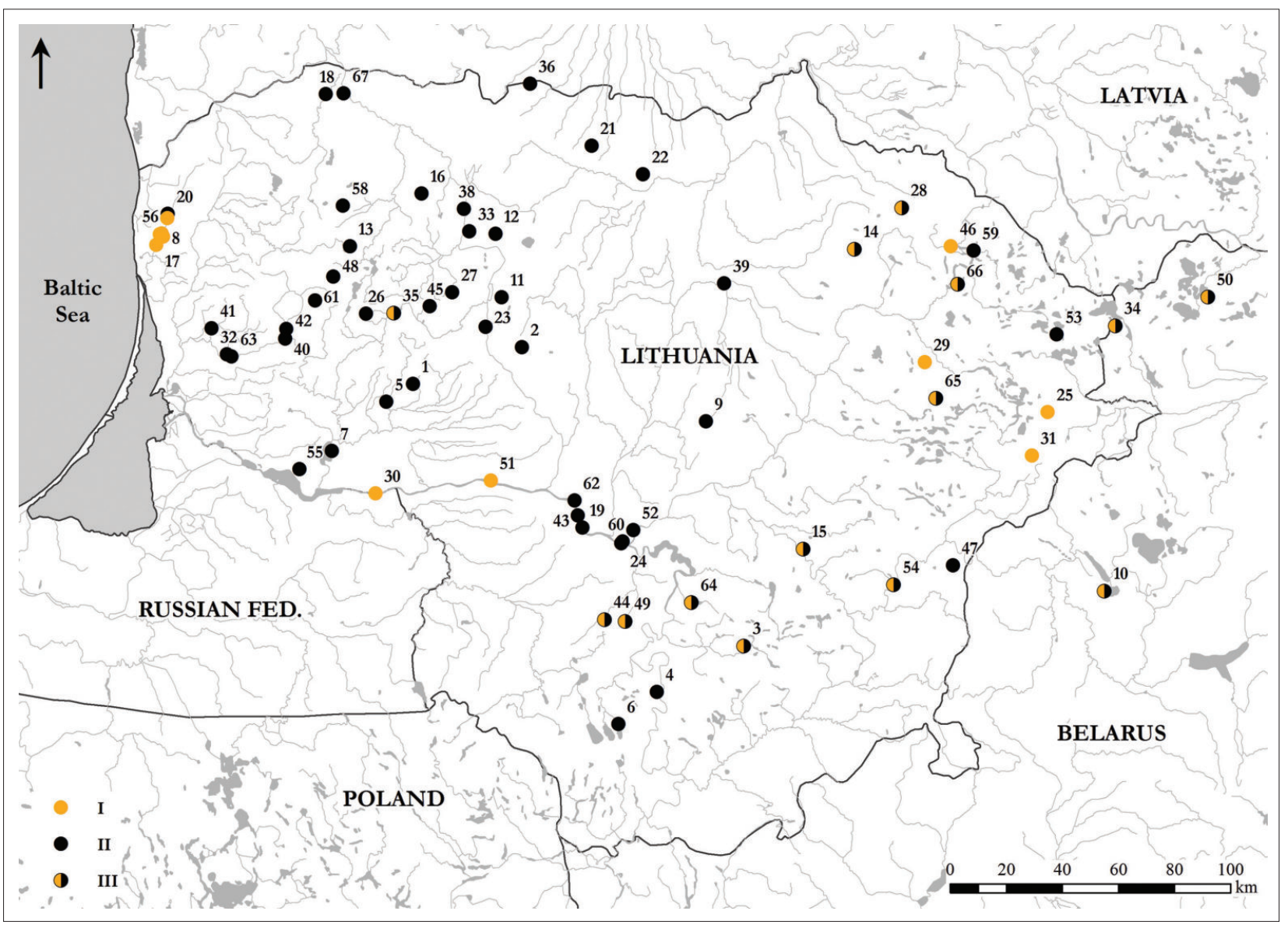

Figure 1. Sites mentioned in the article, dating from the Earliest Iron Age (I), the Early Roman period (II), and from the Earliest Iron Age to the Early Roman period (III). For the site numbers on the map, see Appendix (drawing by G. Petrauskas).

(Podènas 2020) (Fig. 1; Appendix). In contrast, in the coastal lowlands of west Lithuania and the Lower $\mathrm{Ne}$ munas region, the archaeological material comes mainly from burial sites, although there were undoubtedly livedin hillforts and unfortified settlements (Grigalavičiene 1979; Bliujienè et al. 2012; Šiaulinskas 2016; Jovaiša 2020; Minkevičius et al. 2020; Vengalis et al. 2020; Piličiauskas et al. 2021). However, it should be admitted that, in terms of material, chronology and settlement structure, the Earliest Iron Age remains the least-known archaeological period in Lithuania. On one hand, it is difficult to assess more precisely the transition from the Late Bronze Age to the Earliest Iron Age, especially since some of the bronze jewellery was found by chance, and its chronology is defined only by analogies. On the other hand, with the disappearance of bronze axes and other heavy objects characteristic of the Bronze Age, Earliest Iron Age ornaments appear small, which means that they did not require a large amount of copper alloy as a raw material. The low weight of Earliest Iron Age artefacts, mostly jewellery, can be interpreted as a shortage of raw material, most likely due to a disturbance in the raw material exchange network. It could be that bronze ceased to exist on the raw material exchange network in the middle of the 1st millennium BC. In addition, the spread of iron artefacts, including working tools in the Earliest Iron Age, could have influenced changes in people's way of life. Moreover, there is not a great variety of types and shapes among the finds from this period, because the predominant jewellery is pins with cylindrical heads, pins with ring-shaped heads, pins of other shapes, neck-rings, bracelets and ring-shaped temple ornaments. Only a few imported iron fibulae typical of the period in question are known (Grigalavičienè 1995, p. 189, Fig. 108.8). However, the archaeological evidence shows that there was a shortage of iron fibulae in Lithuania during the Earliest Iron Age. This feature is particularly evident, because eye and other fibulae types, and various other kinds of jewellery, spread widely from the Early Roman period onwards. According to data from the 1990s, artefacts made of copper alloys and iron in the hilltop settlements of east and northeast Lithuania accounted for only $2.4 \%$ of the total finds (Luchtanas 1992, p. 68). Although the number of metallic artefacts has increased in recent years, they have not substantially altered our knowledge of this archaeological period. However, the material from barrows (technical ceramics [moulds, crucibles etc], metal 
drops and various kinds of production waste) indicates the presence of local production, which is indicative of a fairly high level of jewellery making, although no permanent production places have yet been found. A reasonable hypothesis is therefore put forward about highly skilled jewellers travelling with the raw materials (Luchtanas et al. 2019; Podènas and Čivilyte 2019). The abundance of technical ceramics and technological studies suggests that most Late Bronze Age artefacts were cast. Bronze was most suitable for casting. By contrast, at the end of the Earliest Iron Age, in addition to casting, the number of artefacts produced from hammered wire and thin tin sheets increased. Technically, malleable brass was most suitable for the production of artefacts by forging. Thus, the change in the elemental composition of copper alloys may have been due to the greater variety of artefacts produced in the east Baltic region at the end of the Earliest Iron Age. The change in alloy, on the other hand, was a European trend that reached northeast Europe fairly quickly.

Artefact production techniques and a reduction in size were the reasons why jewellery came to be shredded. Elemental composition analyses by Optical Emission (OES) and X-ray fluorescence spectrometry (XRF) of a sufficiently representative series of copper alloy ornaments show that Late Bronze Age finds were made of bronze, while in the range of the Earliest Iron Age, jewellery made from brass emerged and spread (Miarkiavichius 1980, pp. 107-109, Table 1; Merkevičius 1986).

However, a distinct shift from bronze to brass alloys can be seen from the middle of the 1st century AD. In other words, the shift to brass coincides with the beginning of the Early Roman period, around circa 40 to 70 AD (i.e. period B1b) (Merkevičius 1973; Vaitkunskienè and Merkevičius 1978, pp. 96-97, Table 1; Čivilytè 2014, p. 44, Table IV.21). The Early Roman period is a time when a sudden jump in the settlement structure covering most of Lithuania is observed, when cultural areas begin to emerge, when a certain divide between the western and eastern parts of the region appears, when striking changes in burial sites and burial customs can be seen, and when a whole range of new forms and types of jewellery appear. These dress accessories might be called pins with a spool-shaped head, neck-rings with hollow shaped trumpet terminals, eye fibulae and several fourth group fibulae according to $\mathrm{O}$. Almgren (1897), temple ornaments, bracelets with budshaped terminals (Merkevičius 1973; 1986; Vaitkunskienè and Merkevičius 1978, Table 1; Bliujienè 2013, pp. 27-28, Table 7, Figs. 335-339). In addition, jewellery manufacturing techniques became more complex. In Lithuania, as in the adjacent regions, in Central Europe, and, of course, in the Roman Empire, brass begins to dominate, and this process coincides with Roman military production, and fits perfectly with the 'industrialisation' of brass, or almost pure brass production in the Roman Empire during the 1st century BC (Craddock 1978, pp. 5-9; Bayley and Butcher 2004, p. 152, Fig. 118). However, in the Roman Empire and provinces, together with brass, some Almgren-type fibulae dating from the mid-1st century to the 2 nd century AD were produced from bronze and gunmetal (Roxburgh et al. 2016, p. 419). A very similar situation in the use of copper alloys is observed for Early Roman period artefacts from Lithuania (Bliujienè et al. 2020, Fig. 7).

\section{Materials and methods}

\section{X-ray fluorescence analysis}

The analysis of copper alloys was carried out on the surface of the artefact by a portable XRF spectrometer Niton XL3t (power $2 \mathrm{~W}$, voltage $50 \mathrm{kV}$, detector area $\sim 50 \mathrm{~mm}^{2}$, producer Thermo Fisher calibration mode 'General Metals'). Each artefact spot was irradiated for 30-35 s (the results did not change after this time). Depending on the configuration and complexity of the artefact, between two and five or more points are examined. This well-known technique of non-destructive surface analysis of objects has already been used widely for several decades (Bayley and Butcher 2004, pp. 21-25; Roxburgh 2016; Roxburgh and Olli 2018). Copper alloys are characterised by their principal alloying elements ( $\mathrm{Zn}, \mathrm{Sn}$ and $\mathrm{Pb}$ ), and the presence of small amounts added main impurities. In the present investigations, use was made of a set of Certified Reference Materials (CRMs), the Cultural Heritage Alloy Reference Material Set (CHARM), originally designed for the analysis of ancient copper alloys, as well as other standard metal reference materials. CRMs provide the possibility to systematically interlink the analytical results of any study (Craddock and Eckstein 2003; Heginbotham et al. 2015).

The results of the analysis of $\mathrm{Cu}, \mathrm{Zn}, \mathrm{Sn}, \mathrm{Pb}, \mathrm{Fe}, \mathrm{Sb}, \mathrm{Ag}$ and $\mathrm{Ni}$ were applied in order to compare the composition of all alloys, although almost all $\mathrm{Ag}$ and $\mathrm{Ni}$ values are below the detected limit, despite the fact that these elements belong to important impurities. Other elements fixed below the setting limit $<$ LOD and/or $0.01-0.1 \%$, or elements that do not affect the composition of the copper alloy and possibly come from the archaeological environment, are not shown in the tables. The mathematical procedure for processing the results and proposing principal conversion formulas is recommended by Pollard et al. (2018, pp. 181183). The XRF results obtained allow for the classification of alloys into copper alloy types according to the main alloying elements (Zn, Sn, Pb) (Bayley and Butcher 2014, p. 14, Fig. 5).

\section{Technological analysis}

Manufacture techniques and decoration of ornaments were defined through the visual examination of artefacts in museums, and by photographing with a digital micro- 
scope (Q-scope 9.0 MP, 200×). During this survey, specific manufacturing features and surface treatment techniques and methods of ornamentation were determined. A detailed visual examination of ornaments, especially for dress pins with wheel-shaped and spool-shaped heads, revealed differently made wax models in casting by the lostwax or cire-perdue technique.

Also, several dress pins were examined, in order to assess their inner construction and the corrosion degree of the iron clasp needle. Radiography was used for understanding the construction of a neck-ring with hollow trumpetshaped terminals. For this task, a portable diagnostic X-ray device IMD E-100R HF E7846 was used. Considering the differences in the thickness of copper alloys and iron, a voltage of $120 \mathrm{kv}$, and exposure of $4 \mathrm{mAs}$ were used. The X-ray images were digitally edited using Adobe Creative Suite software.

Samples of solder, analysed by qualitative micro-chemical analysis, were taken from the neck-ring with hollow trumpet-shaped terminals (see Fig. 11). The microscopic reac- tions of the samples were observed under reflected light using a microscope with a magnification of six to 50 times. Tin and lead metal ions were found in the alloy samples, and this means that a tin-lead solder was used to strengthen components of this neck-ring altogether.

\section{Results and discussion}

The change in the copper alloys and exchange directions

The elemental composition of copper alloys from the Late Bronze Age and the Earliest Iron Age in northeast and east Lithuania shows that, although bronze-type alloys predominate, there is considerable variety in their percentage expression (Table 1; Fig. 2.2). In addition to bronze alloys, artefacts made from leaded bronze and bronze/gunmetal were recorded. Besides this, the first brass-type alloys of brass/gunmetal appear in already the Earliest Iron Age. These are artefacts such as sash-like bracelets with tapered ends found in Nevieriške hillfort, as well as dress pins with

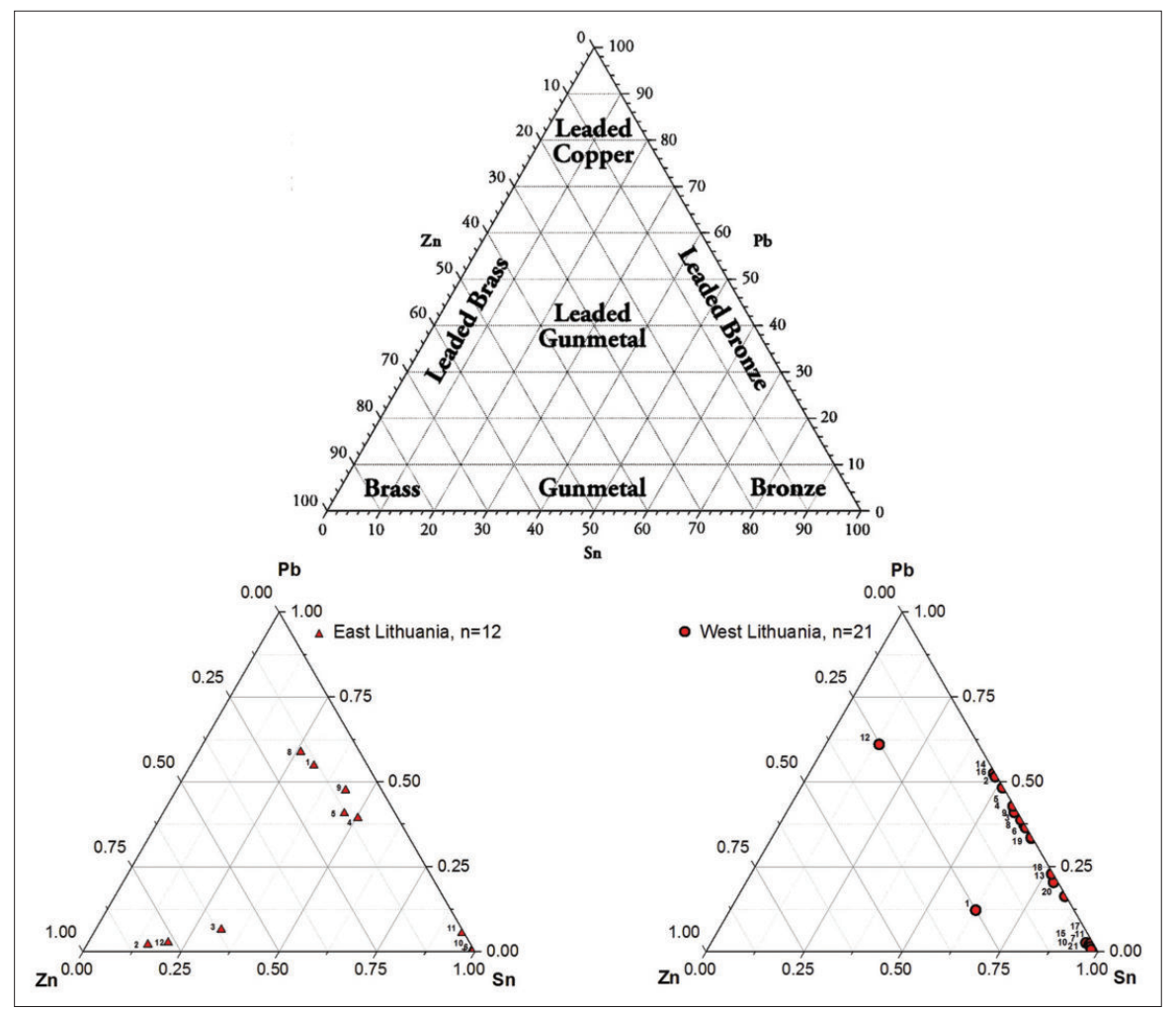

Figure 2. Ternary diagram displaying the $\mathrm{Sn}, \mathrm{Pb}$ and $\mathrm{Zn}$ ratios estimated in alloys of artefacts dated to the Late Bronze Age and the Earliest Iron Age: 1. the alloy classification scheme (after Bayley and Butcher 2004, Fig. 5); 2. artefacts found in east Lithuania; 3. artefacts found in west Lithuania (diagrams by J. Bagdzevičienè). 
Table 1. The results of the X-ray fluorescence analysis of artefacts dated to the end of the Late Bronze Age and the Earliest Iron Age (concentration given in wt\%). For site locations, see Figure 1.

\begin{tabular}{|c|c|c|c|c|c|c|c|c|c|c|c|c|c|c|}
\hline Artefact ID & Site name & Site & Artefact & $\begin{array}{l}\text { Museum } \\
\text { inv. No }\end{array}$ & $\begin{array}{l}\text { Ternary } \\
\text { diagram } \\
\text { ID }\end{array}$ & $\mathrm{Cu}$ & $\mathbf{Z n}$ & Sn & $\mathbf{P b}$ & $\mathrm{Fe}$ & Sb & $\mathbf{A g}$ & $\mathbf{N i}$ & Alloy type \\
\hline \multicolumn{15}{|c|}{ Artefacts from northeast and east Lithuania } \\
\hline Maz.938.5 & Mažulonys & $\begin{array}{l}\text { Foot } \\
\text { settlement }\end{array}$ & Dress pin & $\begin{array}{l}\text { LNM AR } \\
938: 5\end{array}$ & $1 \mathbf{\Lambda}$ & 75.17 & 3.19 & 7.37 & 12.77 & 1.07 & 0.28 & $<$ LOD & $<$ LOD & $\begin{array}{l}\text { Leaded } \\
\text { bronze/gunmetal }\end{array}$ \\
\hline Nev.597.584 & Nevieriškè & Hillfort & Bracelet & $\begin{array}{l}\text { LNM AR } \\
597: 584\end{array}$ & $2 \boldsymbol{\Lambda}$ & 83.84 & 13.04 & 2.45 & 0.34 & 0.22 & 0.05 & $<$ LOD & $<\mathrm{LOD}$ & Brass \\
\hline Nev.597.585 & Nevierišké & Hillfort & Bracelet & $\begin{array}{l}\text { LNM AR } \\
597: 585\end{array}$ & $3 \mathbf{\Lambda}$ & 84.67 & 9.00 & 4.70 & 0.95 & 0.54 & 0.06 & $<$ LOD & $<$ LOD & Gunmetal \\
\hline Sta.109 & Staviškès & Settlement & $\begin{array}{l}\text { Raw } \\
\text { material }\end{array}$ & $\begin{array}{l}\text { LNM (r. s. } \\
109 \text { ) }\end{array}$ & $4 \boldsymbol{\Lambda}$ & 85.86 & 1.17 & 5.84 & 4.56 & 1.72 & 0.25 & 0.50 & $<$ LOD & Leaded bronze \\
\hline Sta.229 & Staviškés & Settlement & $\begin{array}{l}\text { Raw } \\
\text { material }\end{array}$ & $\begin{array}{l}\text { LNM (r. s. } \\
229)\end{array}$ & $5 \boldsymbol{\Lambda}$ & 72.20 & 3.32 & 11.89 & 10.46 & 1.68 & 0.30 & $<\mathrm{LOD}$ & 0.03 & Leaded bronze \\
\hline KerK.1027 & Kernavé & $\begin{array}{l}\begin{array}{l}\text { Kernavė } \\
\text { cemetery }\end{array} \\
\end{array}$ & Dress pin & $\begin{array}{l}\text { KMR A } \\
1027\end{array}$ & $6 \mathbf{\Lambda}$ & 68.93 & 0.14 & 29.15 & 0.17 & 1.13 & 0.04 & $<$ LOD & $<\mathrm{LOD}$ & Bronze \\
\hline KerK.1087 & Kernavé & $\begin{array}{l}\text { Kernavè } \\
\text { cemetery }\end{array}$ & $\begin{array}{l}\text { Temple } \\
\text { ornament }\end{array}$ & $\begin{array}{l}\text { KMR A } \\
1087\end{array}$ & $7 \boldsymbol{\Lambda}$ & 67.18 & 0.00 & 29.86 & 0.00 & 2.14 & $<$ LOD & $<$ LOD & $<$ LOD & Bronze \\
\hline KerK.1451 & Kernavé & $\begin{array}{l}\text { Kernavè } \\
\text { cemetery }\end{array}$ & Finger-ring & $\begin{array}{l}\text { KMR A } \\
1451\end{array}$ & $8 \boldsymbol{\Delta}$ & 80.68 & 2.34 & 4.09 & 9.18 & 1.73 & 0.07 & 1.43 & $<$ LOD & $\begin{array}{l}\text { Leaded } \\
\text { bronze/gunmetal }\end{array}$ \\
\hline KerK.3896 & Kernavé & $\begin{array}{l}\text { Kernavè } \\
\text { cemetery }\end{array}$ & $\begin{array}{l}\text { Fragment } \\
\text { of unknown } \\
\text { purpose }\end{array}$ & $\begin{array}{l}\text { KMR A } \\
3896\end{array}$ & $9 \boldsymbol{\Lambda}$ & 68.92 & 2.59 & 12.17 & 13.37 & 1.98 & 0.40 & 0.24 & $<$ LOD & Leaded bronze \\
\hline KerK.1324 & Kernavè & $\begin{array}{l}\text { Kernavė } \\
\text { cemetery }\end{array}$ & $\begin{array}{l}\text { Fragment } \\
\text { of unknown } \\
\text { purpose }\end{array}$ & $\begin{array}{l}\text { KMR A } \\
1324\end{array}$ & $10 \boldsymbol{\Lambda}$ & 30.22 & 0.21 & 63.55 & 0.26 & 2.55 & 0.21 & $<$ LOD & 0.25 & Bronze \\
\hline KerK.4420 & Kernavé & $\begin{array}{l}\text { Kernavè } \\
\text { cemetery }\end{array}$ & Staples & \begin{tabular}{|l|} 
KMR A \\
4420
\end{tabular} & $11 \mathbf{\Lambda}$ & 75.36 & 0.12 & 22.59 & 1.33 & 0.25 & 0.05 & $<$ LOD & $<$ LOD & Bronze \\
\hline Petr.1505.47 & Petrešiūnai & Hillfort & Dress pin & $\begin{array}{l}\text { VDKM AR } \\
1505: 47\end{array}$ & $12 \boldsymbol{\Lambda}$ & 83.09 & 12.35 & 3.28 & 0.43 & 0.63 & 0.09 & $<$ LOD & $<$ LOD & Brass/gunmetal \\
\hline \multicolumn{15}{|c|}{ Artefacts from west Lithuania } \\
\hline Paa.136 & Paalksniai & \begin{tabular}{|l} 
Barrow \\
cemetery
\end{tabular} & Dress pin & $\begin{array}{l}\text { LNM (r. s } \\
136)\end{array}$ & $1 \bullet$ & 63.66 & 7.10 & 17.77 & 3.47 & 7.43 & 0.14 & 0.09 & 0.04 & Bronze/gunmetal \\
\hline Vilu.2021.1.3 & Vilūnai & Find spot & Dress pin & LNM & $2 \bullet$ & 43.42 & 0.08 & 27.61 & 25.89 & 1.85 & 0.47 & 0.43 & 0.07 & Leaded bronze \\
\hline Egl.636.1 & Égliškiai & $\begin{array}{l}\text { Barrow } \\
\text { cemetery }\end{array}$ & $\begin{array}{l}\text { Temple } \\
\text { ornament }\end{array}$ & $\begin{array}{l}\text { LNM AR } \\
636: 1\end{array}$ & $3 \bullet$ & 60.11 & 0.06 & 23.89 & 14.26 & 0.89 & 0.32 & 0.33 & 0.05 & Leaded bronze \\
\hline Egl.636.2 & Égliškiai & $\begin{array}{l}\text { Barrow } \\
\text { cemetery }\end{array}$ & Dress pin & $\begin{array}{l}\text { LNM AR } \\
636: 2\end{array}$ & $4 \bullet$ & 44.95 & 0.44 & 30.64 & 21.65 & 0.69 & 0.31 & 0.19 & 0.06 & Leaded bronze \\
\hline Egl.636.3 & Égliškiai & $\begin{array}{l}\begin{array}{l}\text { Barrow } \\
\text { cemetery }\end{array} \\
\end{array}$ & Bracelet & $\begin{array}{l}\text { LNM AR } \\
636: 3\end{array}$ & $5 \bullet$ & 53.74 & 0.10 & 26.02 & 19.61 & 0.16 & 0.25 & $<$ LOD & 0.03 & Leaded bronze \\
\hline Egl.636.4 & Égliškiai & $\begin{array}{l}\text { Barrow } \\
\text { cemetery }\end{array}$ & Bracelet & $\begin{array}{l}\text { LNM AR } \\
636: 4\end{array}$ & $6 \bullet$ & 44.71 & 0.15 & 35.33 & 17.85 & 1.17 & 0.09 & 0.49 & $<$ LOD & Leaded bronze \\
\hline Egl.636.7 & Ėgliškiai & $\begin{array}{l}\text { Barrow } \\
\text { cemetery }\end{array}$ & Neck-ring & $\begin{array}{l}\text { LNM AR } \\
636: 7\end{array}$ & $7 \bullet$ & 82.08 & 0.17 & 16.96 & 0.34 & 0.12 & 0.08 & $<\mathrm{LOD}$ & 0.07 & Bronze \\
\hline Egl.636.9 & Égliškiai & $\begin{array}{l}\text { Barrow } \\
\text { cemetery }\end{array}$ & Bracelet & $\begin{array}{l}\text { LNM AR } \\
636: 9\end{array}$ & $8 \bullet$ & 43.91 & 0.08 & 34.45 & 19.92 & 0.35 & 0.64 & 0.37 & 0.06 & Leaded bronze \\
\hline Egl.636.11 & Ėgliškiai & $\begin{array}{l}\text { Barrow } \\
\text { cemetery }\end{array}$ & $\begin{array}{l}\text { Temple } \\
\text { ornament }\end{array}$ & $\begin{array}{l}\text { LNM AR } \\
636: 11\end{array}$ & $9 \bullet$ & 70.19 & 0.06 & 17.02 & 10.84 & 1.53 & 0.18 & $<\mathrm{LOD}$ & 0.04 & Leaded bronze \\
\hline Egl.636.12 & Égliškiai & $\begin{array}{l}\text { Barrow } \\
\text { cemetery }\end{array}$ & Pendant & $\begin{array}{l}\text { LNM AR } \\
636: 12\end{array}$ & $10 \bullet$ & 94.54 & 0.07 & 4.03 & 0.11 & 0.99 & 0.05 & $<\mathrm{LOD}$ & 0.14 & Bronze \\
\hline Egl.636.13 & Égliškiai & $\begin{array}{l}\text { Barrow } \\
\text { cemetery }\end{array}$ & Pendant & $\begin{array}{l}\text { LNM AR } \\
636: 13\end{array}$ & $11 \bullet$ & 93.09 & 0.08 & 6.30 & 0.14 & 0.12 & 0.02 & $<$ LOD & 0.04 & Bronze \\
\hline Egl.636.16 & Ėgliškiai & $\begin{array}{l}\text { Barrow } \\
\text { cemetery }\end{array}$ & Bracelet & $\begin{array}{l}\text { LNM AR } \\
636: 16\end{array}$ & $12 \bullet$ & 82.16 & 4.33 & 2.33 & 10.45 & 0.31 & 0.16 & 0.22 & $<$ LOD & $\begin{array}{l}\text { Leaded } \\
\text { gunmetal }\end{array}$ \\
\hline Egl.636.17 & Égliškiai & $\begin{array}{l}\text { Barrow } \\
\text { cemetery }\end{array}$ & Workpiece & $\begin{array}{l}\text { LNM AR } \\
636: 17\end{array}$ & $13 \bullet$ & 67.56 & 0.35 & 24.87 & 6.48 & 0.25 & 0.20 & 0.22 & 0.05 & Leaded bronze \\
\hline Egl.636.25 & Égliškiai & $\begin{array}{l}\text { Barrow } \\
\text { cemetery }\end{array}$ & Neck-ring & $\begin{array}{l}\text { LNM AR } \\
636: 25\end{array}$ & $14 \bullet$ & 56.40 & 0.15 & 20.07 & 22.35 & 0.47 & 0.31 & $<$ LOD & 0.08 & Leaded bronze \\
\hline Egl.636.39 & Égliškiai & $\begin{array}{l}\text { Barrow } \\
\text { cemetery }\end{array}$ & Pendant & $\begin{array}{l}\text { LNM AR } \\
636: 39\end{array}$ & $15 \bullet$ & 86.18 & 0.08 & 12.57 & 0.33 & 0.59 & 0.13 & $\angle \mathrm{LOD}$ & 0.05 & Bronze \\
\hline Egl.636.40 & Égliškiai & $\begin{array}{l}\text { Barrow } \\
\text { cemetery }\end{array}$ & Pendant & $\begin{array}{l}\text { LNM AR } \\
636: 40\end{array}$ & $16 \bullet$ & 80.02 & 0.08 & 9.38 & 10.06 & 0.33 & 0.06 & $<\mathrm{LOD}$ & 0.09 & Leaded bronze \\
\hline Egl.636.45 & Ėgliškiai & $\begin{array}{l}\text { Barrow } \\
\text { cemetery }\end{array}$ & Dress pin & $\begin{array}{l}\text { LNM AR } \\
636: 45\end{array}$ & $17 \bullet$ & 92.87 & 0.07 & 6.06 & 0.09 & 0.72 & 0.04 & $<\mathrm{LOD}$ & 0.05 & Bronze \\
\hline Rau.530.8 & Raudonènai & Cemetery & $\begin{array}{l}\text { Temple } \\
\text { ornament }\end{array}$ & $\begin{array}{l}\text { LNM AR } \\
530: 8\end{array}$ & $18 \bullet$ & 53.58 & 0.12 & 30.31 & 9.03 & 6.58 & 0.16 & $<$ LOD & $<$ LOD & Leaded bronze \\
\hline Rau.530.9 & Raudonènai & Cemetery & $\begin{array}{l}\text { Temple } \\
\text { ornament }\end{array}$ & $\begin{array}{l}\text { LNM AR } \\
530: 9\end{array}$ & $19 \bullet$ & 43.42 & 0.09 & 36.50 & 18.56 & 1.13 & 0.12 & $<$ LOD & 0.07 & Leaded bronze \\
\hline Naud.27 & Naudvaris & Cemetery & $\begin{array}{l}\text { Temple } \\
\text { ornament }\end{array}$ & $\begin{array}{l}\text { LNM (r. s. } \\
\text { 27) }\end{array}$ & $20 \bullet$ & 68.19 & 0.08 & 25.99 & 5.09 & 0.44 & 0.14 & $\angle \mathrm{LOD}$ & $<$ LOD & Leaded bronze \\
\hline Naud.28 & Naudvaris & Cemetery & $\begin{array}{l}\text { Temple } \\
\text { ornament }\end{array}$ & $\begin{array}{l}\text { LNM (r. s. } \\
28 \text { ) }\end{array}$ & $21 \bullet$ & 63.84 & 0.46 & 32.00 & 0.20 & 324 & $<$ LOD & $<$ LOD & 0.07 & Bronze \\
\hline
\end{tabular}




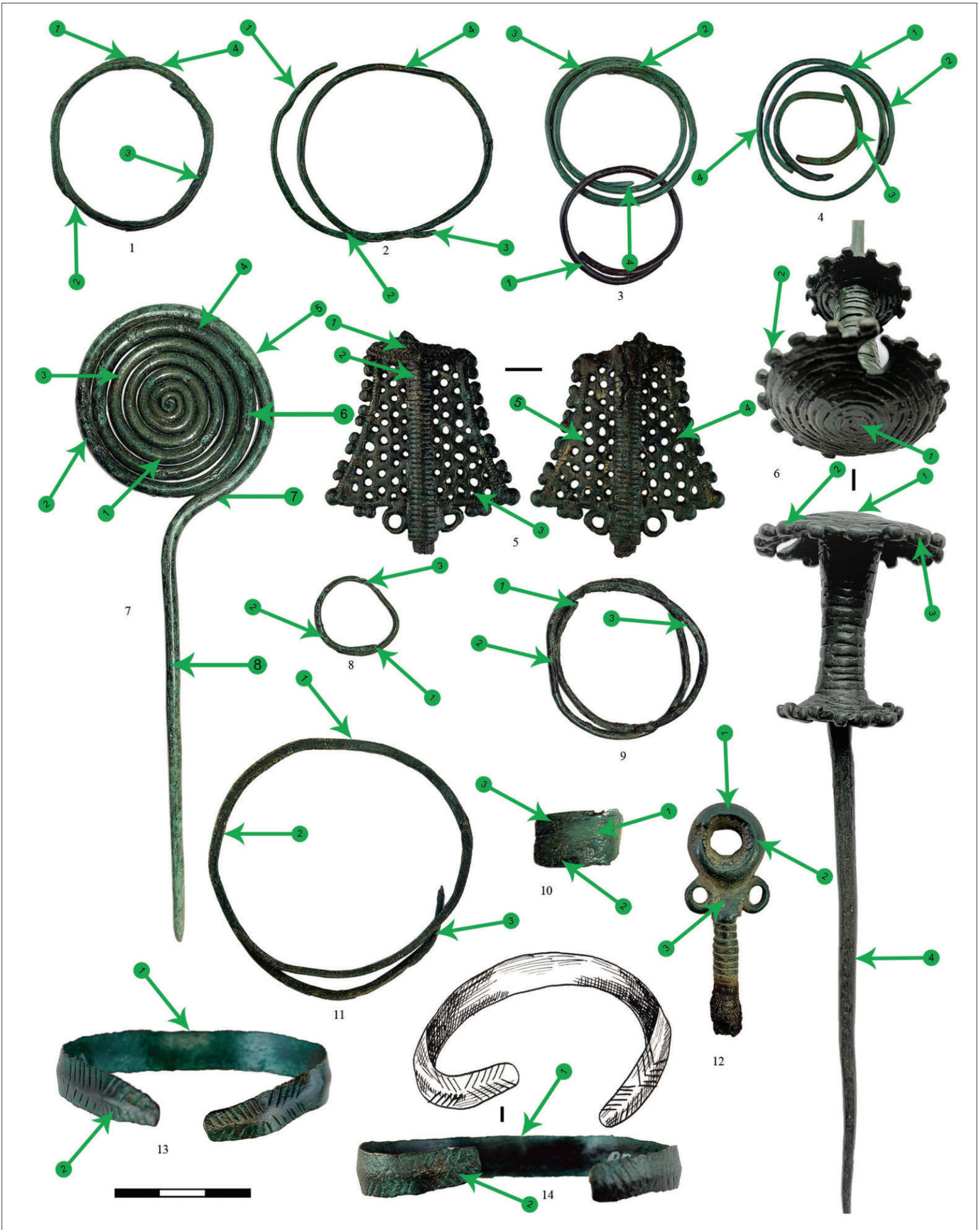

Figure 3. Ornaments found in inhumation and cremation graves dating from the 5th century BC to the 1st century AD: 1, 2. Naudvaris cemetery, grave 8 (LNM GRD 98389); 3, 4. Raudonenai cemetery, grave 3 (LNM AR 530:8, 9); 5. Paalksniai barrow cemetery, stray find in barrow 5 mound (LNM GRD 68594); 6. Mažulonys, foot settlement, trench 18 (LNM AR 938:5); 7. Kernave cemetery, grave 9 (KMR A 1027); 8. Kernavé cemetery, grave 8 (KMR A 1087); 9, 10. Kernavé cemetery, stray finds (KMR A 1451); 11. Pilviškès barrow cemetery, barrow 1, grave 1 (LNM AR 906:1); 12. Vilūnai, stray find (LNM); 13, 14. Nevieriškés hillfort, trench 5 (LNM AR 597:584, 585). Spots investigated by XRF method marked with green arrows (photographs by A. Bliujiene, drawing from the LNM, Departament of Prehistoric Archaeology Collections cards catalogue). 


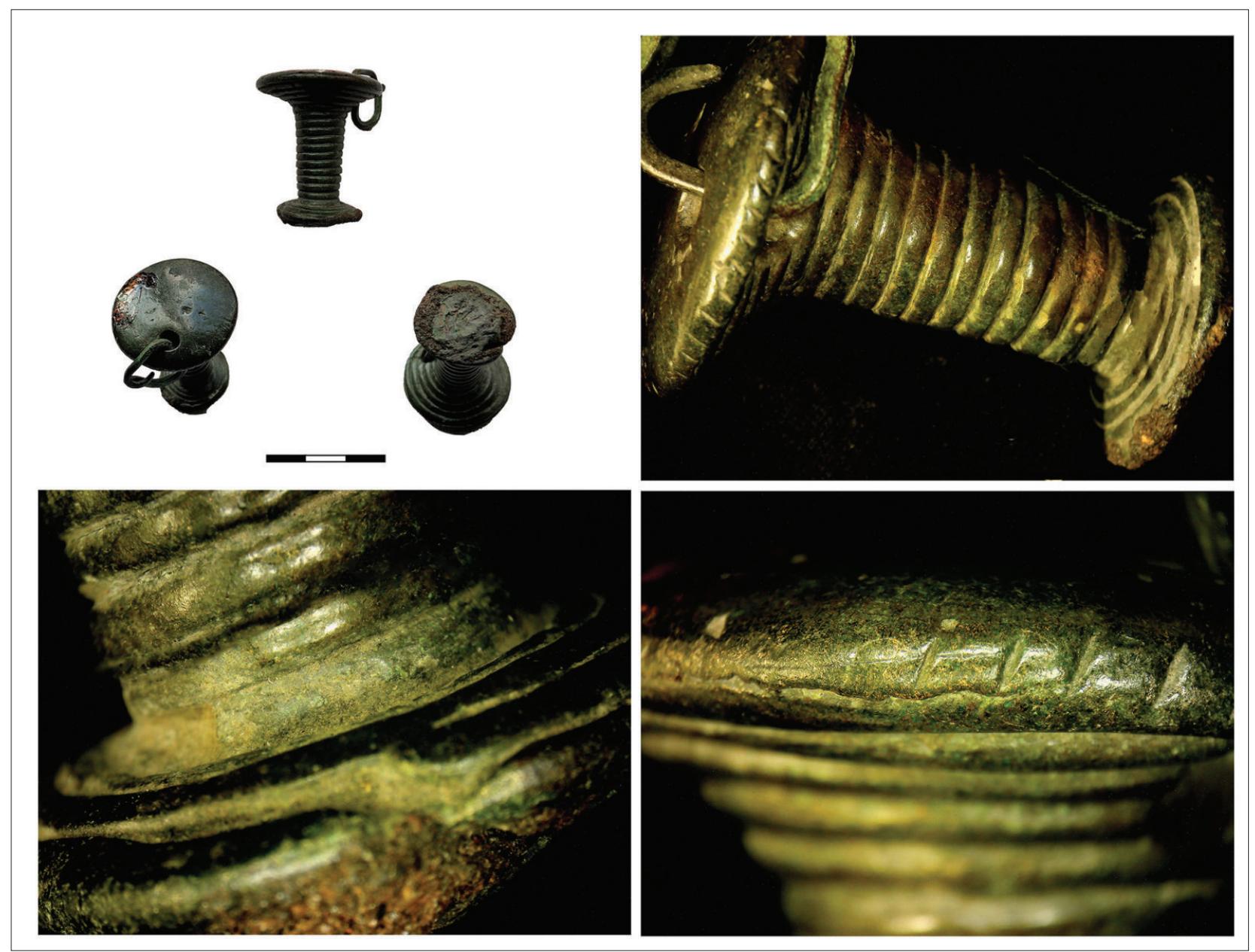

Figure 4. The bronze dress pin with a spool-shaped head from Petrešiunai hillfort (VDKM AR 1505:47) (photographs by A. Bliujienè, enlarged $50 \times$ photographs by E. Babenskas).

spool-shaped heads and an iron clasp needle of a similar chronology found in Petrešiūnai hillfort (Figs. 3.13, 14 and 4). The emergence of brass in Lithuania in the 1st century $\mathrm{BC}$ is not an exceptional fact, because during the 1st millennium BC the use of brass alloys spread across a wide geographical area touched by Roman civilisation (Craddock 1978).

The variation in the northeast and eastern alloys studied may not be due to changes in the sources of the raw material, but rather to the use of scrap metal and the remelting of alloys. However, it is clear that there were some links between the inhabitants of northeast and eastern Lithuania and northeast forest zone societies, as is evident by the exchange of artefacts and cultural ideas (Fig. 3.5). It is possible that the Baltic Sea region was already part of the chain of the exchange of metal raw materials between Scandinavia via the Baltic islands (Öland, Gotland, Saaremaa) to Daugava, and further northeast and the VolgaKama region, in the Bronze Age. That would explain how in the Earliest Iron Age the same communication chain functioned, thus at least partly elucidating the relations between east Lithuania and the forest zone of northeast Europe (Luchtanas and Sidrys 1999, p. 26; Lang 2007, p. 184; Vasks 2010, pp. 156-158; Čivilytė 2014, pp. 52-53, 146; Podènas and Čivilyte 2019). Therefore, it is probable that the axes and large rings that spread in the east Baltic region in the context of the Bronze Age were part of this exchange network. However, there is not enough data so far to show that the metal raw material came from the east, although the Kargaly ore mines (the steppes of the southern Urals), where copper ore was mined in the Bronze Age, was one of the centres (Čivilyte 2014, pp. 5253). Still, copper ore from the Kargaly mines was used by locals (Kuzminykh 1983, pp. 157-161; Chernykh 2002), so it is likely that the exchange going down the line, or even directional exchange networks, had to have a reverse exchange product, which could have been metal products or raw material. Of course, it is not easy to determine what exchange equivalent was used by societies in east Lithuania in the Bronze Age.

The elemental composition of copper alloys from the Late Bronze Age to the Earliest Iron Age in west 
Lithuania shows that, although leaded bronze and bronzetype alloys predominate, these alloys are more homogeneous (Figs. 2.3 and 5). The archaeological material shows that during this period, west Lithuania was in contact with south and southwest regions, central Scandinavia, and the Baltic Sea islands. It can therefore be assumed that nonferrous metals were obtained from western and Central European ore mines (Miarkiavichius 1980, p. 110; Vasks 2010, p. 156; Čivilyte 2014, p. 140). The largest tin deposits in Europe are in the west of the Iberian Peninsula and in Cornwall in southwest Britain, and in the Erzgebirge crossing Bohemia and Germany. There were also smaller occurrences of tin ore in Brittany, southeast France, Serbia, Tuscany in northwest Italy, on Sardinia, and in western Slovakia (Radivojević et al. 2018, Figs. 1 and 4; with references therein; Stos-Gale 2019, pp. 98-104, Fig. 3).

Since brass products appeared in Lithuania at the end of the Earliest Iron Age, it seems that the spread of brass in Europe was encouraged by exports and influences from the Middle East and the eastern Mediterranean, where the production of brass alloys from metallic copper and zinc ore was initiated (Stos-Gale 2019). However, the Romans made brass (auricalcum) famous and affordable when they came up with the invention of a new technique called cementation, and began making brass coins and military equipment at a state level (Dungworth 1997, p. 903; Bayley and Butcher 2004, p. 13). In technical terms, auricalcum was an alloy of copper and zinc, which was absorbed into the metal in a specialised metallurgical process called cementation. It appears that the use of brass increased over this period, making up around $40 \%$ of all copper alloys used in the Roman world by the 4 th century AD (StosGale 2017).

In Lithuania, a significant change in the elemental composition of copper alloys and the production of artefacts took place in the middle of the 1st century $\mathrm{AD}$, and this was an epoch-making change. As is evident from Lithuanian archaeological material, brass started to dominate in the Early Roman period. However, although brass-type alloys predominate, it is obvious that gunmetal was equally popular (Tables 2, 3; Figs. 6 and 7). It is important to note that the elemental alloy composition of eye fibulae of the second half of the 1st and the 2nd century AD found in Lithuania, in general, corresponds to that of the copper alloys used in northern Roman provinces, and Central and northeast Europe (cf. Pietrzak 1997; Andrzejowski 1998; Gan 2015; Pauli 2019; Bliujienè et al. 2020; Łuczkiewicz et al. 2022 in press). Also, it should be mentioned that the zinc content in Roman brass (auricalcum) was around 17\% to $21 \%$, or from $22 \%$ to $28 \%$. However, it seems that craftsmen could then add further alloying elements, such as tin or lead obtained from scrap bronze. Therefore, the absorption of zinc in the cementation process was reduced due to the lower melting point of copper (Craddock 1978; Jout- tijärvi 2009; 2017; Hammer and Voß 2011; Łuczkiewicz et al. 2022 in press). As far as is known, during the 1st and 2nd centuries AD and later in the Roman Empire and the Barbaricum, the zinc content in copper alloys was steadily declining, and the composition of the alloy was changing over time for different reasons (cf. Dungworth 1997, p. 907; Pollard et al. 2015, pp. 700-706). Recycling copper alloys affected scieties living in Lithuania and the east Baltic region, where raw materials were only acquired via exchange. The process of recycling copper alloys can also be seen in the XRF results. Alloys and/or scrap metal reached present-day Lithuania through a complex and long exchange chain, using different exchange equivalents. The elemental composition of copper alloys in the Bronze and Earliest Iron Ages and the Early Roman period followed the same rhythm as in Europe.

\section{The characterisation of the archaeological background applying to artefact production technologies}

During the Late Bronze Age and Earliest Iron Age, dress pins with spiral heads, some with a small conical boss in the middle, pendants and spiral temple ornaments were common in the east Baltic region (Grigalavičiene 1995, Fig. 105; Lang 2007, Fig. 111.2) (Figs. 3.1-4, 7-9 and $5.1,7-12)$. There were also neck-rings with pointed and hoofed ends, sash-like and spiral bracelets, and rings (Figs. 3.10-13, 14 and 5.6, 13, 14). Besides these common jewellery types, dress pins with wheel-shaped heads and open-work heads appear. At the end of the Earliest Iron Age, dress pins with spool-shaped heads and other finds close to this type are known from fortified settlements in northeast Lithuania. All these pins are characterised by iron clasp needles (Figs. 3.5, 12; 4; 5.5).

In terms of production technique, Earliest Iron Age artefacts continued to be cast using the cire perdue technique, but there was an increase in the use of hammered wire and small artefacts produced from thin tin sheets. A sophisticated cast-on technique also emerged, which was adapted for dress pins with wheel-shaped, spool-shaped and open-work heads, their massive heads being cast on to the iron clasping needle of the future pin (Figs. 4; 8.1; $9.1,3,4)$. The tightening copper alloy firmly encased the iron clasp needle, saving copper alloy. A piece of a dress pin with a wheel-shaped head was found at the Ėgliškiai burial mound site (barrow 2, inhumation grave 1) in west Lithuania. The pin has a wheel-shaped head and two loops on both sides of the iron clasp needle. Loops produced as an imitation of filigree plaited from two wires were made from a cutting wax model (Figs. 5.5 and 9.1). This is one of the first cases when an imitation of filigree work has been noted in the Earliest Iron Age. A clasp needle is inserted into the pin head up to the top of the wheel. In addition, 


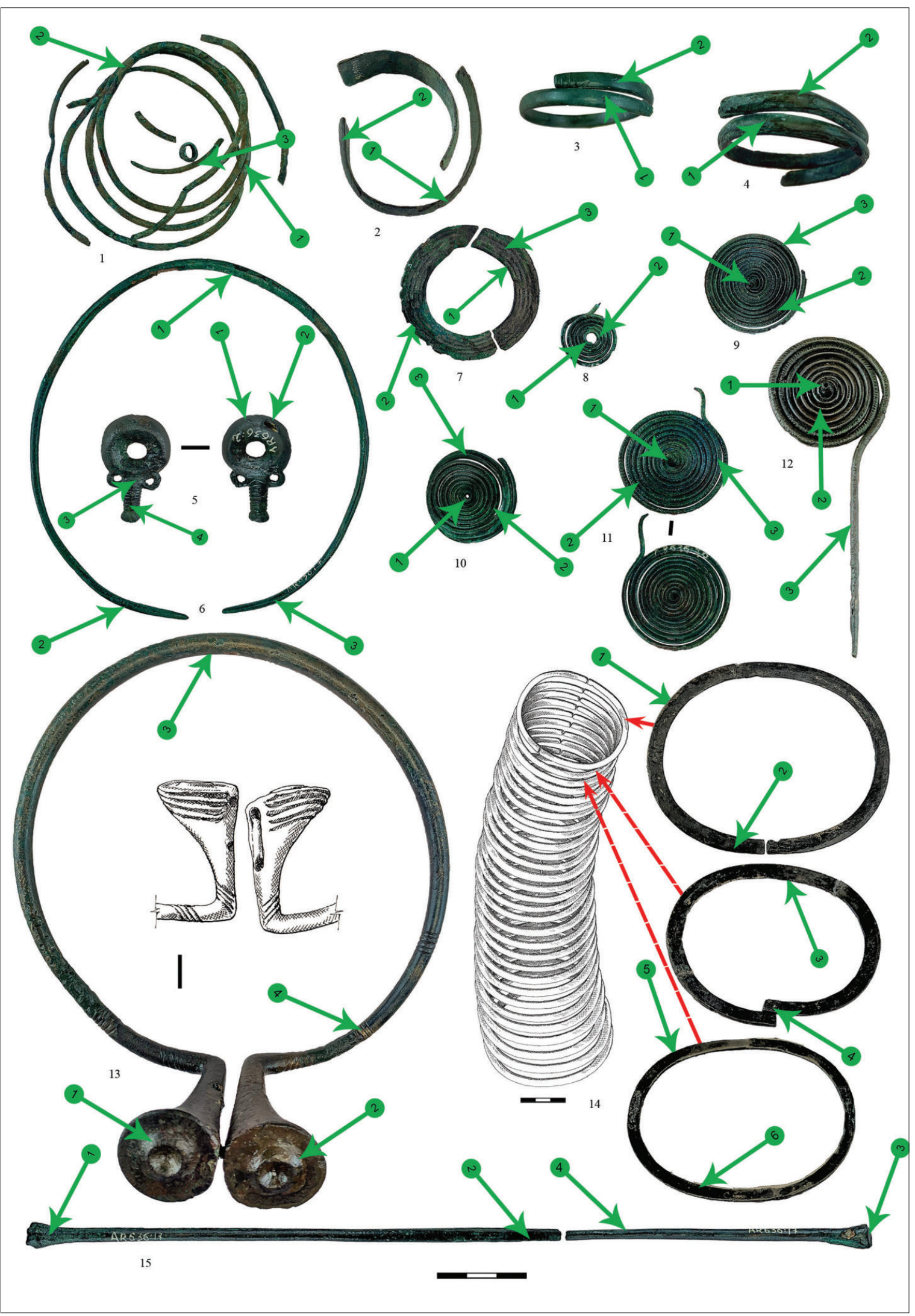

Figure 5. Ornaments found in inhumation graves in Ėgliškiai barrow cemetery from the 1st century BC to the turn of the 1st century AD: 1. barrow 1 in mound (LNM AR 636:1); 2, 15. barrow 3, grave 3 (LNM AR 636:16, 17); barrow 2, grave (LNM AR 636:4); 4, 6, 7. barrow 3, grave 1 (LNM AR 636:7, 9, 11); 5, 14. barrow 2, grave 1 (LNM AR 636:2, 3); 8, 9. barrow 3, grave 2 (LNM AR 636:12, 13); 10-12. barrow 3 , grave 8 (LNM AR 636:39, 40, 45); 13. barrow 3 , grave 5 (LNM AR 636:25). Spots investigated by XRF method marked with green arrows (photographs by A. Bliujiene, drawing from LNM, Departament of Prehistoric Archaeology Collections card catalogue). 
Table 2. The results of the X-ray fluorescence analysis of (concentration given in wt\%). dress pins with a spool-shaped head dated to the Early Roman period. For site locations, see Figures 1 and 10.

\begin{tabular}{|c|c|c|c|c|c|c|c|c|c|c|c|c|c|}
\hline Artefact ID & Site name & Site & $\begin{array}{l}\text { Museum } \\
\text { inv. No }\end{array}$ & $\begin{array}{l}\text { Ternary } \\
\text { diagram } \\
\text { ID }\end{array}$ & $\mathrm{Cu}$ & $\mathbf{Z n}$ & Sn & $\mathbf{P b}$ & $\mathbf{F e}$ & Sb & Ag & $\mathbf{N i}$ & Alloy type \\
\hline Paa.118 & Paalksniai & $\begin{array}{l}\text { Barrow } \\
\text { cemetery }\end{array}$ & $\begin{array}{l}\text { LNM (r. } \\
\text { s. 118) }\end{array}$ & $1=$ & 79.01 & 4.20 & 12.22 & 2.36 & 1.94 & 0.13 & $<\mathrm{LOD}$ & $<\mathrm{LOD}$ & Bronze/gunmetal \\
\hline Paa.302 & Paalksniai & $\begin{array}{l}\text { Barrow } \\
\text { cemetery }\end{array}$ & $\begin{array}{l}\text { LNM (r. } \\
\text { s. } 302)\end{array}$ & $2=$ & 83.85 & 8.21 & 4.87 & 0.58 & 2.26 & 0.13 & $<\mathrm{LOD}$ & $<\mathrm{LOD}$ & Gunmetal \\
\hline Pas.657.5 & Paštuva & Cemetery & $\begin{array}{l}\text { VDKM } \\
\text { AR } \\
657: 5\end{array}$ & $3=$ & 78.99 & 10.74 & 7.99 & 0.65 & 1.44 & 0.16 & $<\mathrm{LOD}$ & $<$ LOD & Gunmetal \\
\hline San.1588.23 & $\begin{array}{l}\text { Akmenė } \\
\text { (Sandrausiškè) }\end{array}$ & $\begin{array}{l}\text { Barrow } \\
\text { cemetery }\end{array}$ & $\begin{array}{l}\text { VDKM } \\
\text { AR } \\
1588: 23\end{array}$ & 4 ! & 82.33 & 6.58 & 6.78 & 1.40 & 2.62 & 0.17 & $<\mathrm{LOD}$ & $<\mathrm{LOD}$ & Gunmetal \\
\hline Sar.1229.35 & Sargènai & Cemetery & $\begin{array}{l}\text { VDKM } \\
\text { AR } \\
\text { 1229:35 }\end{array}$ & $5=$ & 80.59 & 10.09 & 7.20 & 1.26 & 0.69 & 0.11 & $<\mathrm{LOD}$ & $<\mathrm{LOD}$ & Gunmetal \\
\hline Sar.1229.48 & Sargènai & Cemetery & $\begin{array}{l}\text { VDKM } \\
\text { AR } \\
1229: 48\end{array}$ & $6=$ & 75.33 & 11.34 & 8.89 & 2.90 & 0.84 & 0.17 & $<\mathrm{LOD}$ & 0.04 & Gunmetal \\
\hline Sar.1229.54 & Sargènai & Cemetery & $\begin{array}{l}\text { VDKM } \\
\text { AR } \\
\text { 1229:54 }\end{array}$ & 7 = & 85.57 & 7.10 & 1.99 & 0.38 & 4.86 & 0.09 & $<\mathrm{LOD}$ & $<\mathrm{LOD}$ & Brass/gunmetal \\
\hline Sar.1616.126 & Sargènai & Cemetery & $\begin{array}{l}\text { VDKM } \\
\text { AR } \\
\text { 1616:126 }\end{array}$ & 8 = & 72.94 & 15.93 & 4.97 & 1.43 & 3.90 & 0.14 & $<\mathrm{LOD}$ & 0.02 & Brass/gunmetal \\
\hline Pri.641.2 & Pribitka & $\begin{array}{l}\text { Barrow } \\
\text { cemetery }\end{array}$ & $\begin{array}{l}\text { LNM } \\
\text { AR } \\
641: 2\end{array}$ & 9 a & 71.09 & 6.48 & 3.91 & 0.41 & 17.89 & 0.11 & $<$ LOD & $<$ LOD & Gunmetal \\
\hline Cig.101 & Cigoniškiai & Cemetery & $\begin{array}{l}\text { LNM (r. } \\
\text { s. } 302 \text { ) }\end{array}$ & $10=$ & 51.59 & 2.22 & 19.28 & 22.92 & 3.35 & $<$ LOD & 0.24 & 0.06 & Leaded bronze \\
\hline
\end{tabular}

Table 3. The results of the X-ray fluorescence analysis (concentration given in wt $\%)$ of Early Roman period ornaments.

Abbreviations for site names: Kur. - Kurmaičiai; Nik. - Nikėlai; Str. - Strazdai (Ječiškès); Pri. - Pribitka; Vie. - Vienragiai; Keg. - Kègai; Ada. - Adakavas; Dau. - Dauglaukis; Bat. - Batakiai; Med. - Medvėgalis; Paju. - Pajūralis; Paa - Paalksniai; Per. - Perkūniškè; San. - Sandrausiškė; Kyb. - Kybartiške;; Jon. - Jonelaičiai; Mai. - Maironiai (Saudininkai); Vil. - Vilkija; Pas. - Paštuva; Sar. - Sargėnai; Kau. - Kaunas district; Vos. - Vosgèliai; Radn. - find site unknown; Pap. - Papiliai (Skomantai); Tel. - Telšiai; Nol. - Noliškiai; Zas. - Zastaučiai; Kuk. - Kukiai (Petreliai); Paba - Pabaliai; Gla. - Glaušiai; Par. - Paragaudis; Tol. - Toleikiai (Thaleiken-Jacob).

\begin{tabular}{|c|c|c|c|c|c|c|c|c|c|c|c|c|}
\hline Artefact ID & Artefact types & $\begin{array}{l}\text { Museum } \\
\text { inv. No }\end{array}$ & $\begin{array}{l}\text { Ternary } \\
\text { diagram } \\
\text { ID }\end{array}$ & $\mathrm{Cu}$ & $\mathbf{Z n}$ & Sn & $\mathbf{P b}$ & $\mathbf{F e}$ & Sb & $\mathbf{A g}$ & $\mathrm{Ni}$ & Alloy type \\
\hline Kur.1.63 & Eye fibula A61 type & LNM AR 1:63 & 10 & 86.04 & 4.14 & 8.33 & 0.75 & 0.59 & 0.14 & $<$ LOD & $<\mathrm{LOD}$ & Bronze/gunmetal \\
\hline Kur.1.64 & Eye fibula A61 type & LNM AR 1:64 & 20 & 60.53 & 23.60 & 11.16 & 2.01 & 1.95 & 0.31 & $<$ LOD & 0.03 & Gunmetal \\
\hline Kur.1.98 & $\begin{array}{l}\text { Triangular foot. third A group. } \\
\text { close to A64 type }\end{array}$ & LNM AR 1:98 & 30 & 81.16 & 7.64 & 8.95 & 0.83 & 1.13 & 0.20 & $<$ LOD & $<$ LOD & Gunmetal \\
\hline Kur.1.118 & Eye fibula A61 type & LNM AR 1:118 & $4 \circ$ & 79.10 & 4.40 & 9.84 & 5.58 & 0.77 & 0.25 & $<$ LOD & $<$ LOD & $\begin{array}{l}\text { Leaded } \\
\text { bronze/gunmetal }\end{array}$ \\
\hline Kur.1.119 & Eye fibula $\mathrm{A} 60$ type & LNM AR 1:119 & $5 \circ$ & 80.14 & 13.13 & 4.08 & 0.33 & 0.50 & 0.35 & $<$ LOD & $\angle \mathrm{LOD}$ & Brass/gunmetal \\
\hline Kur.1.126 & Eye fibula A61 type & LNM AR 1:126 & 60 & 88.21 & 5.45 & 4.42 & 1.05 & 0.69 & 0.14 & $<$ LOD & $<$ LOD & Gunmetal \\
\hline Kur.1.129 & $\begin{array}{l}\text { Eye fibula A61 type (recomposed } \\
\text { into a crossbow fibula) }\end{array}$ & LNM AR 1:129 & 70 & 81.86 & 5.57 & 4.42 & 1.13 & 6.78 & 0.23 & $<$ LOD & $<$ LOD & Gunmetal \\
\hline Kur.1.156 & Eye fibula A61 type & LNM AR 1:156 & $8 \circ$ & 79.46 & 14.70 & 4.40 & 0.52 & 0.47 & 0.14 & $<$ LOD & 0.02 & Brass/gunmetal \\
\hline Kur.1.174 & Fibula of $\mathrm{A}$ fourth group 93 type & LNM AR 1:174 & 90 & 82.22 & 6.89 & 9.43 & 0.53 & 0.74 & 0.13 & $<$ LOD & $<$ LOD & Gunmetal \\
\hline Kur.1.175 & Fibula of A fourth group & LNM AR 1:175 & $10 \circ$ & 84.55 & 9.10 & 3.80 & 0.94 & 1.26 & 0.15 & $<$ LOD & $<$ LOD & Gunmetal \\
\hline Nik.832.2 & Fibula A second group. 42 type & VDKM AR 823:2 & 110 & 82.15 & 8.97 & 6.48 & 0.99 & 0.75 & 0.15 & $<$ LOD & $\angle \mathrm{LOD}$ & Gunmetal \\
\hline Nik.832.3 & Fibula of $\mathrm{A}$ fourth group 72 type & VDKM AR 823:3 & $12 \circ$ & 88.29 & 4.34 & 4.68 & 0.97 & 1.46 & 0.23 & $<$ LOD & 0.03 & Gunmetal \\
\hline Nik.832.4 & Fibula of $\mathrm{A}$ fourth group 93 type & VDKM AR 823:4 & $13 \circ$ & 83.22 & 7.28 & 7.79 & 0.68 & 0.81 & 0.16 & $<$ LOD & $<$ LOD & Gunmetal \\
\hline Str.859.31 & $\begin{array}{l}\text { Fragment of fibula with a } \\
\text { triangular foot }\end{array}$ & LNM AR 859:31 & 140 & 83.67 & 3.24 & 7.32 & 1.18 & 3.76 & 0.36 & 0.23 & $<$ LOD & Bronze/gunmetal \\
\hline
\end{tabular}




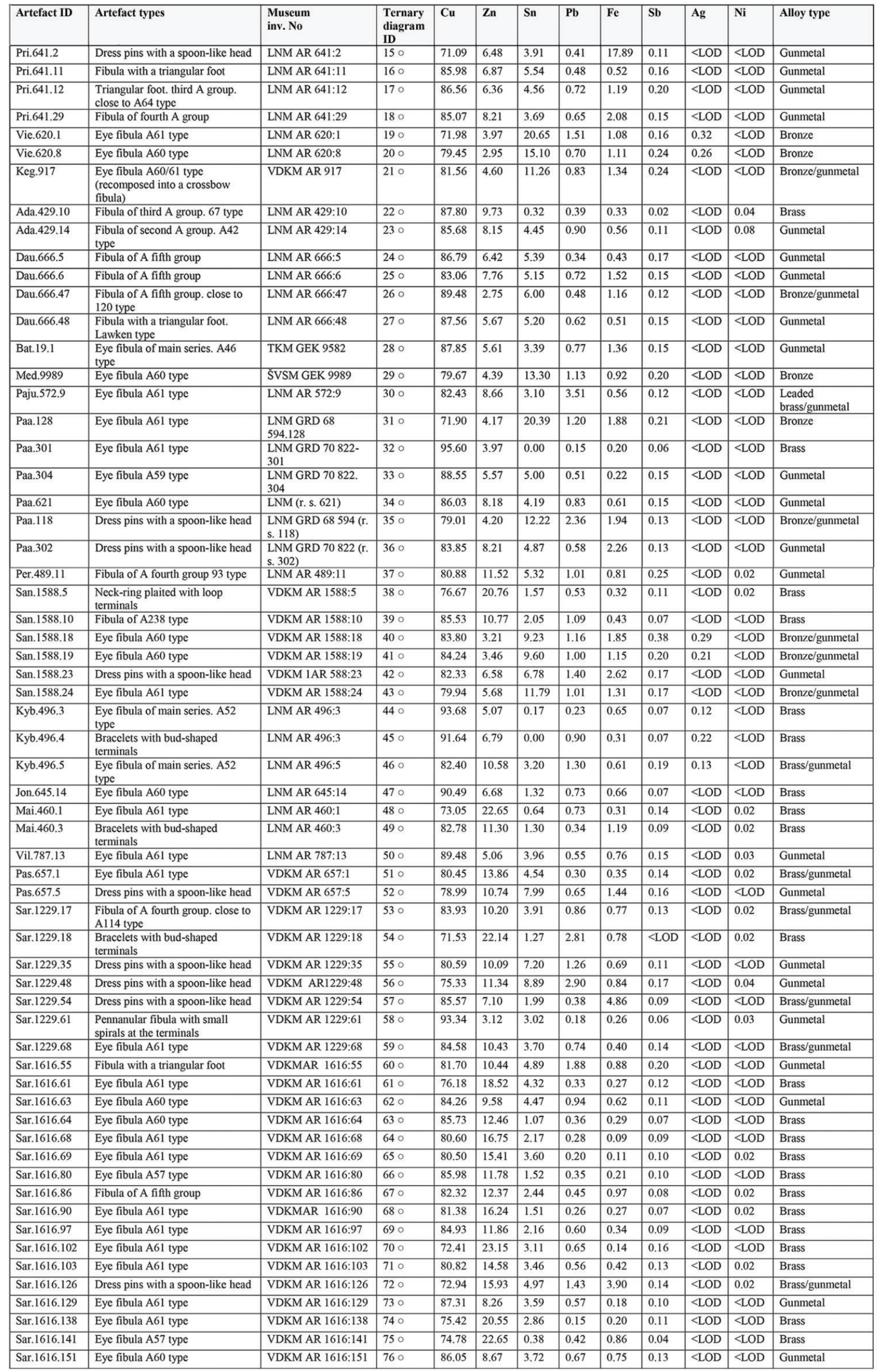




\begin{tabular}{|c|c|c|c|c|c|c|c|c|c|c|c|c|}
\hline Artefact ID & Artefact types & $\begin{array}{l}\text { Museum } \\
\text { inv. No }\end{array}$ & $\begin{array}{l}\text { Ternary } \\
\text { diagram } \\
\text { ID }\end{array}$ & $\mathbf{C u}$ & $\mathbf{Z n}$ & Sn & $\mathbf{P b}$ & $\mathbf{F e}$ & Sb & $\mathbf{A g}$ & $\mathbf{N i}$ & Alloy type \\
\hline Sar.1616.170 & $\begin{array}{l}\text { Bracelets with bud-shaped } \\
\text { terminals }\end{array}$ & VDKM AR 1616:170 & $77 \circ$ & 79.36 & 14.85 & 0.33 & 0.17 & 0.34 & 0.10 & $<$ LOD & $<\mathrm{LOD}$ & Brass \\
\hline Sar.1616.179 & Eye fibula A61 type & VDKAR AR 1616:179 & $78 \circ$ & 72.25 & 19.05 & 5.47 & 1.57 & 1.07 & 0.13 & $<\mathrm{LOD}$ & 0.02 & Brass/gunmetal \\
\hline Sar.1616.185 & $\begin{array}{l}\text { Fibula of A fourth group. close to } \\
\text { A72 type }\end{array}$ & VDKM AR 1616:185 & $79 \circ$ & 83.62 & 12.30 & 1.96 & 0.53 & 0.42 & 0.11 & $<$ LOD & 0.01 & Brass \\
\hline Sar.1616.187 & Eye fibula close to A57 type & VDKM AR 1616:187 & $80 \circ$ & 76.40 & 7.90 & 11.73 & 2.61 & 1.07 & 0.08 & $<$ LOD & $<$ LOD & Gunmetal \\
\hline Sar.1616.219 & Fibula close to A238 type & VDKM AR 1616:219 & $81 \circ$ & 85.61 & 10.96 & 0.58 & 0.59 & 0.57 & 0.06 & $<$ LOD & $<$ LOD & Brass \\
\hline Sar.1616.224 & Eye fibula close to A57 type & VDKM AR 1616:224 & $82 \circ$ & 81.93 & 11.99 & 2.39 & 0.46 & 0.24 & 0.05 & $<$ LOD & 0.02 & Brass \\
\hline Sar.1616.225 & Fibula of A238 type & VDKM AR 1616:225 & $83 \circ$ & 85.10 & 9.46 & 2.98 & 1.51 & 0.89 & 0.05 & $<$ LOD & $<\mathrm{LOD}$ & Brass/gunmetal \\
\hline Sar.1780.10 & Eye fibula A61 type & VDKM AR 1780:10 & $84 \circ$ & 84.79 & 9.00 & 4.48 & 0.57 & 0.98 & 0.13 & $<$ LOD & $<$ LOD & Gunmetal \\
\hline Sar.1780.11 & $\begin{array}{l}\text { Fibula of A fourth group. close to } \\
\text { A72 type }\end{array}$ & VDKM AR 1780:11 & $85 \circ$ & 80.18 & 14.45 & 3.02 & 0.66 & 0.80 & 0.10 & $<\mathrm{LOD}$ & 0.02 & Brass \\
\hline Sar1817.75 & Eye fibula A61 type & VDKM AR 1817:75 & $86 \circ$ & 75.66 & 13.94 & 8.98 & 0.67 & 0.55 & 0.14 & $<\mathrm{LOD}$ & 0.02 & Gunmetal \\
\hline Sar.1817.77 & Eye fibula A59 type & VDKM 1817:77 & $87 \circ$ & 72.89 & 11.11 & 13.06 & 1.76 & 0.69 & 0.26 & $<\mathrm{LOD}$ & $<\mathrm{LOD}$ & Gunmetal \\
\hline Kau.58.6 & Eye fibula A59 type & LNM AR 58:6 & $88 \circ$ & 66.69 & 27.59 & 0.12 & 0.74 & 0.67 & 0.22 & $<$ LOD & 0.02 & Brass \\
\hline Kau.58.7 & Eye fibula A61 type & LNM AR 58:7 & $89 \circ$ & 69.29 & 26.81 & 2.85 & 0.45 & 0.17 & 0.10 & $<$ LOD & $<\mathrm{LOD}$ & Brass \\
\hline Kau.58.8 & Eye fibula A59 type & LNM AR 58:8 & $90 \circ$ & 73.78 & 19.08 & 4.53 & 0.27 & 0.65 & 0.17 & $<\mathrm{LOD}$ & 0.02 & Brass \\
\hline Vos.75.16 & Eye fibula A59 type & LNM AR 75:16 & $91 \circ$ & 89.09 & 7.15 & 1.47 & 0.42 & 1.05 & 0.13 & $<$ LOD & $<$ LOD & Brass \\
\hline Radn.710.17 & Fibula of $A$ fourth group 72 type & VDKM AR 710:17 & $92 \circ$ & 82.33 & 13.87 & 2.80 & 0.26 & 0.62 & 0.08 & $<$ LOD & 0.02 & Brass \\
\hline Radn.1678.1 & Eye fibula A57 type & VDKM AR 1678:1 & $93 \circ$ & 85.34 & 7.60 & 4.39 & 1.87 & 0.59 & 0.13 & $<$ LOD & $<\mathrm{LOD}$ & Gunmetal \\
\hline Radn.2129 & Fibula of $\mathrm{A}$ fourth group 72 type & VDKM AR 2129 & $94 \circ$ & 82.63 & 10.28 & 5.49 & 0.75 & 0.65 & 0.14 & $<$ LOD & 0.03 & Gunmetal \\
\hline Pap.2055 & Fibula of $\mathrm{A}$ fourth group & ŽAM A 2055 & $95 \circ$ & 83.11 & 7.31 & 6.27 & 1.62 & 1.03 & 0.22 & 0.16 & 0.07 & Gunmetal \\
\hline Pap.2063 & Eye fibula A60 type & ŽAM A 2063 & $96 \circ$ & 87.23 & 8.75 & 2.51 & 0.79 & 0.60 & 0.10 & $<$ LOD & $<\mathrm{LOD}$ & Brass/gunmetal \\
\hline Tel.723 & $\begin{array}{l}\text { Prussian series eye fibula } \\
\text { fragment }\end{array}$ & ŽAM A 723 & $97 \circ$ & 74.60 & 6.38 & 14.37 & 1.80 & 2.04 & 0.27 & 0.13 & $<$ LOD & Bronze/gunmetal \\
\hline KurL.45.184 & Fibula with a triangular foot & JIKM AR 45:184 & $98 \circ$ & 77.44 & 12.77 & 3.70 & 0.77 & 0.86 & 0.15 & $<$ LOD & $<\mathrm{LOD}$ & Brass/gunmetal \\
\hline KurL.45.183 & Eye fibula A61 type & JIKM AR 45:183 & $99 \circ$ & 73.80 & 3.85 & 13.50 & 1.39 & 2.41 & 0.21 & 0.19 & $<\mathrm{LOD}$ & Bronze \\
\hline Nol.16.2 & Eye fibula A61 type & ŠAM A-L 16:2 & $100 \circ$ & 78.53 & 11.51 & 7.70 & 0.65 & 1.11 & 0.22 & $<$ LOD & $<\mathrm{LOD}$ & Gunmetal \\
\hline Zas.5146 & $\begin{array}{l}\text { Bracelets with bud-shaped } \\
\text { terminals }\end{array}$ & MM GEK 5146 & $101 \circ$ & 84.63 & 8.45 & 4.49 & 0.65 & 0.55 & 0.52 & 0.28 & 0.20 & Gunmetal \\
\hline Zas.5105 & Eye fibula A59 type & MM GEK 5105 & $102 \circ$ & 82.70 & 10.67 & 5.25 & 0.51 & 0.63 & 0.10 & $<$ LOD & $<\mathrm{LOD}$ & Gunmetal \\
\hline Zas.5096 & Eye fibula A60 type & MM GEK 5096 & $103 \circ$ & 82.59 & 4.95 & 9.22 & 1.41 & 1.44 & 0.21 & $<$ LOD & $<\mathrm{LOD}$ & Bronze/gunmetal \\
\hline Zas.5084 & Eye fibula A57 type & MM GEK 5084 & $104 \circ$ & 81.63 & 12.65 & 2.47 & 0.45 & 0.32 & 0.10 & $<\mathrm{LOD}$ & $<$ LOD & Brass \\
\hline Zas.5099 & Eye fibula A61 type & MM GEK 5099 & $105 \circ$ & 85.26 & 11.57 & 2.08 & 0.54 & 0.33 & 0.09 & $<\mathrm{LOD}$ & $<\mathrm{LOD}$ & Brass \\
\hline Zas.5105 & Eye fibula A61 type & MM GEK 5105 & $106 \circ$ & 88.16 & 5.48 & 4.98 & 0.24 & 0.73 & 0.21 & $<$ LOD & $<\mathrm{LOD}$ & Gunmetal \\
\hline Zas.5143 & Eye fibula A59 type & MM GEK 5143 & $107 \circ$ & 74.55 & 6.89 & 13.44 & 2.60 & 1.48 & 0.32 & 0.31 & $<\mathrm{LOD}$ & Bronze/gunmetal \\
\hline Zas.5083 & $\begin{array}{l}\text { Fibula of } A \text { fourth group. close to } \\
84 \text { type }\end{array}$ & MM GEK 5083 & $108 \circ$ & 71.08 & 0.31 & 6.37 & 20.72 & 1.02 & 0.11 & $<$ LOD & 0.07 & Leaded bronze \\
\hline Kuk.4220 & Eye fibula $\mathrm{A} 60$ type & MM GEK 4220 & $109 \circ$ & 84.78 & 6.89 & 2.37 & 1.16 & 4.41 & 0.15 & $<$ LOD & $<$ LOD & Brass/gunmetal \\
\hline Paba.93 & $\begin{array}{l}\text { Fibula of } \mathrm{A} \text { fourth group. } 93 \\
\text { group }\end{array}$ & JIKM GEK & $110 \circ$ & 83.12 & 7.02 & 6.91 & 0.67 & 1.82 & 0.14 & 0.13 & $<$ LOD & Gunmetal \\
\hline Paba.92 & $\begin{array}{l}\text { Fibula of A fourth group. close to } \\
92 \text { type }\end{array}$ & JIKM GEK & 1110 & 63.29 & 4.29 & 19.88 & 8.43 & 1.57 & 0.53 & 1.60 & $<\mathrm{LOD}$ & Leaded bronze \\
\hline Gla.830 & Neck-ring with hollow terminals & KKM 830 & $112 \circ$ & 77.72 & 5.40 & 11.44 & 10.04 & 0.16 & $<\mathrm{LOD}$ & $<$ LOD & $<$ LOD & $\begin{array}{l}\text { Leaded } \\
\text { bronze/gunmetal }\end{array}$ \\
\hline Par.721.20 & Eye fibula A57 type & LNM AR 721: 20 & $113 \circ$ & 82.45 & 6.39 & 9.88 & 0.47 & 0.57 & 0.14 & $<$ LOD & $<$ LOD & Bronze/gunmetal \\
\hline Par.721.49 & Eye fibula A61 type & LNM AR 721: 49 & $114 \circ$ & 80.18 & 7.23 & 9.85 & 0.89 & 1.45 & 0.30 & $<$ LOD & $<$ LOD & Gunmetal \\
\hline Par.721.68 & Eye fibula A60 type & LNM AR 721: 68 & $115 \circ$ & 82.78 & 3.70 & 8.81 & 0.84 & 3.48 & 0.30 & $<$ LOD & $<$ LOD & Bronze/gunmetal \\
\hline Par.721.81 & Eye fibula A61 type & LNM AR 721: 81 & $116 \circ$ & 84.69 & 9.37 & 4.56 & 0.74 & 0.38 & 0.13 & $<$ LOD & $<\mathrm{LOD}$ & Gunmetal \\
\hline Par.721.93 & Eye fibula A57 type & LNM AR 721: 93 & $117 \circ$ & 71.81 & 3.88 & 22.14 & 0.66 & 0.78 & 0.30 & 0.31 & $<$ LOD & Bronze \\
\hline Par.721.147 & Eye fibula A52 type & LNM AR 721: 147 & $118 \circ$ & 84.38 & 11.91 & 2.31 & 0.46 & 0.62 & 0.12 & $<\mathrm{LOD}$ & $<\mathrm{LOD}$ & Brass \\
\hline Par.721.150 & Eye fibula A52 type & LNM AR 721: 150 & $119 \circ$ & 90.03 & 5.16 & 3.11 & 0.74 & 0.77 & 0.15 & $<$ LOD & $<\mathrm{LOD}$ & Gunmetal \\
\hline Par.721.167 & Eye fibula A59 type & LNM AR 721: 167 & $120 \circ$ & 87.27 & 6.01 & 5.74 & 0.19 & 0.68 & 0.10 & $<$ LOD & $<$ LOD & Gunmetal \\
\hline Tol.70127 & Eye fibula A46 type & MLIM GEK 70127 & $121 \circ$ & 86.09 & 8.24 & 2.72 & 1.20 & 0.90 & 0.15 & $<$ LOD & $<\mathrm{LOD}$ & Brass/gunmetal \\
\hline
\end{tabular}

in the production of the wax model, thin strips of wax are wrapped around an iron fastening needle. This technique of making pins creates an ornament of concentric circles around the iron clasp needle (Figs. 4 and 8.3,4). Two more imitations of filigree wires were fixed on to a cast spiraldisc temple ornament found at Ėgliškiai barrow cemetery (barrow 3, grave 1), and a dress pin from Paalksniai (Grigalavičienè 1979, p. 28.1; Michelbertas 2010, Fig. 1; 2011, Fig. 35) (Figs. 3.5 and 5.7). The imitation of filigree was done by casting. Cast spiral-disc temple ornaments were ornamented in this way in the Early Roman period.

The dress pins with a wheel-shaped head and two loops from Égliškiai had no analogues in the archaeological ma- terial from the end of the Earliest Iron Age in Lithuania for quite a long time (Grigalavičienè 1979, Fig. 14; Grigalavichene 1980, p. 84, Table XXX.2; Merkevičius 2011, p. 33). In 2020, at the village of Vilūnai in southern Lithuania, during rescue excavations at the construction of an international gas pipeline, a similar pin type to the Égliškiai piece, with a wheel-shaped head and loops, was found (Figs. 3.12; 5.5; 8.3, 4). The Ėgliškiai and Vilūnai dress pins are linked not only by the shape of the jewellery, but also by the technique of wax model production, which is characteristic of the Earliest Iron Age. The Petrešiūnai dress pin with a spool-shaped head was cast using the same cire perdue technique, and thin strips of wax were wrapped 
around an iron fastening needle (Fig. 4). The dress pins with wheel-shaped heads from Ėgliškiai and Vilūnai fall within the cultural area of West Baltic barrows, which has been distinguished in west Lithuania mainly on the basis of burial sites (Grigalavičienè 1995, pp. 240-242; Brazaitis 2005, pp. 309-323). A technically close analogue of the pin is known in Estonia, found south of Tartu. This pin also has a wheel-shaped head and two loops in its lower part (Jaanits et al. 1982, pp. 186-187). According to Lang (2007, p. 184), pins made from a combination of bronze and iron originate in the Volga, Oka and Dnieper regions.

The next artefact examined in this paper was found in west Lithuania, at Paalksniai barrow cemetery, in destroyed barrow 5 mound. Only two artefacts, without any human remains, were found in this burial mound. One of these is a fragment of a dress pin with an open-work head and temple ornament in the shape of a spiral-disc (Michelbertas 2011, pp. 36-37). The pin is fragmented, with damage to its head and a lost iron clasp needle (Fig. 4.5). XRF analysis of the fragment indicates that its head is made of bronze/gunmetal. The head of the pin is trapeze-shaped open-work, with the edges adorned by cast granules. Two loops are formed at the lower part of the pin head, similar to the above-mentioned finds from Égliškiai and Vilūnai. The fragment of a pin head from Paalksniai has been incorrectly associated with the leaf-shaped pin found at Moškėnai (Laukupenai) hillfort in northeast Lithuania (Krzywicki 1917, Table XIII; Michelbertas 2010, pp. 6266; 2011, p. 75; Merkevičius 2011, p. 85). However, the pin found at Moškènai (Laukupenai) and the specimen from Paalksniai reveal differences in their shape and some technical aspects. In particular, the specimen from Moškènai (Laukupenai) lacks an open-work part of the pin, and the head does not contain loops formed on both sides of the iron clasp needle. The head of the Moškenai (Laukupenai) pin is directly linked with the shaft, whereas the Paalksniai piece extends to both sides, forming two wing-shaped features. The artefact found at Moškenai (Laukupènai) hillfort has direct analogies with pins found in the Smolensk and St Petersburg regions, and according to the typology compiled by A.A. Chubur (2012), they are classified as type seven. In this typology, the pin found at Paalksniai would most closely correspond to type four common to the territory between the rivers Desna and Seim (Sejm), and which has an open-work head with a wing-shaped widening in the lower part of the head (Chubur 2012, p. 119, Figs. 1 and 5; Shpilev 2018, and the references therein). Leaf-shaped pins of various types were common in the Earliest Iron Age in the vast area between the left bank of the Dnieper and the Oka. They all have their massiveness, their close shape and decorative elements in common; but above all, their iron clasp needles, like a vertical compositional axis, runs the entire length of the head of the pin, and, like a reflection in a mirror, divides the arte- facts into two equal parts. There are no direct analogies so far between the pins found at Paalksniai and in the region on the left bank of the Dnieper and the Oka. However, the Paalksniai pin is definitely based on inherited production techniques and ornamental traditions. It cannot be ruled out that the pin came from the east as a commodity or raw material. The chronology of these pins here is also not entirely clear, but the aforementioned researchers place them between the 4 th and 2 nd centuries BC. The dress pin from Paalksniai might be dated to the Earliest Iron Age (Luchtanas and Sidrys 1999, Supplement 3). It is most likely that this pin came to Paalksniai already broken as scrap metal around the 2nd or 1st centuries BC. In Paalksniai barrow 5, where the fragment of pin was found, there are traces of a cultural layer, pieces of slag and shards of smooth-skinned moulded pottery. Shards of brushed pottery were also found in the filling of other Paalksniai barrows (Michelbertas 2011, pp.79-80). On the basis of the cultural layer recorded in the mound filling samples and the finds, it can be assumed that there was a settlement in the area dating from the 2 nd or 1st century $\mathrm{BC}$ to the 1 st century $\mathrm{AD}$, before the barrows began to be built. Thus, the chronology of the pin may coincide with the chronology of the settlement, and does not contradict similar ornaments from those found between the Dnieper and the Oka.

Another type of late Earliest Iron Age and Early Roman period pin is dress pins with spool-shaped heads. This type of pin, judging by its prevalence, may have originated in the Earliest Iron Age in the area of Brushed Pottery culture. Its origins lie in the pins with antler or bone heads and iron needles known in northeast Lithuania. These tools could have served both as pins and as awls. Bone-headed pins have been found in the Gorani, Kereliai, Nurviany and Vorènai hillforts (Kulikauskienè and Rimantienè 1958, Fig. 202; Grigalavičienè 1992, p. 90, Fig. 10.11; Egore chchenko 2006, p. 88, Table 61.1-3) (Figs. 1 and 10). The heads of spool-shaped pins found in Belarus, both bone and copper alloy, have holes (Egoreǐchenko 2006, Table 61.1-5). The head of the bone pins is coil-shaped (length about $3-5 \mathrm{~cm}$, diameter of head about $2 \mathrm{~cm}$ ), and is quite massive. Both bone and copper alloy spool-shaped pins found in Ratiunki have holes in their heads, and this feature connects them with the pin found in Petrešiunai hillfort (Fig. 4) As was mentioned, the technique and shape of this pin is close to that of Earliest Iron Age pieces, although it is made of brass/gunmetal. This confirms the fact that the first brass alloys in Lithuania date from the 2nd or 1st century BC. A pin similar in shape to coils was found in the settlement at the foot of the Mažulionys hillfort (Kliaugaite 2006, p. 30, Fig. 14) (Fig. 3.6). This pin has a hole in the head, into which a chain or a cord would have been inserted to secure the fastening of the garment. However, due to a casting defect, the hole was left open. 
The Mažulionys pin is decorated with concentric circles clumsily incised in the wax model, while the edges of the pin are decorated with imitations of cast granules.

In the Early Roman period, spool-shaped with copper alloy heads and iron needles are placed in group $\mathrm{H}$ or the first group (Beckmann 1969, Abb. 1; Michelbertas1986, pp. 124-127, Fig. 43.1, 2). These pins are made from brass and gunmetal, but there is evidence of when spoolshaped pins were produced from lead bronze (Table 2). Iron pins of this type were found in Aukštadvaris hillfort and in Sargenai burial ground, grave No 280. The use of iron and copper alloy in the production of these pins is interpreted as saving raw material for copper alloy. Judging by the size of the heads of the dress pins with a spoolshaped head, these were massive ornaments, with heads weighing between either 14 and 37 grams, with an average of 27 grams. Pins with spool-shaped heads and iron clasp needles date from the second half of the 1st century to the middle of the 2 nd century $\mathrm{AD}$, and were spread in the area of Late Brushed Pottery culture in the northeast, east and southwest. Individual pins of this group are found in the western part of Belarus (Egoreĭchenko 2006, p. 88). However, west of the River Šventoji, the number of spoolshaped pins decreases, as does the spread of Brushed Pottery culture. Higher concentrations are known in cemeteries of Early Roman period centres at the confluence of the Nemunas and Neris and in the western area of Samogitian barrow cemeteries (Michelbertas1986, pp. 124-127). Spool-shaped pins did not spread in the burial sites of west Lithuania and the lower reaches of the Nemunas (Fig. 10). Therefore, it can be argued that the contact and influence of Late Brushed Pottery culture and in the forest zone of northeast Europe ended in the Samogitian highlands.

The neck-rings with hollow trumpet-shaped terminals worn in the Early Roman Iron Age are the most fashionable pieces of jewellery produced using multiplex techniques that required highly skilled jewellers (Fig. 11). The prototypes for these neck-rings came from the La Tène and Roman cultural legacy, and were later absorbed by Germanic people. In the lands of the Balts, the idea of such neck-rings was adopted from similar Scandinavian gold neck-rings (Rzeszotarska-Nowakiewicz 2010). In terms of territorial distribution and social significance, these technically elaborate neck-rings stand in contrast to the contemporaneous ornaments, such as the dress pins with spool-shaped heads or eye fibulae discussed in this article (Bliujienè et al. 2020). Simplified versions of these neckrings made of copper alloy in the third quarter of the 1st century to the middle of the 2 nd century AD spread to Lithuania, the Finno-Ugric tarand area in northern Latvia, and sometime later to northeast Estonia, as well as the southwest coast of Finland.
With regard to the manufacturing technique, neck-rings with hollow trumpet-shaped terminals are the most technically sophisticated, the largest (the diameter is from 22 to $26 \mathrm{~cm}$ ), and the heaviest (they weigh between 213 and 314 grams, and even up to 508 grams) Early Roman period jewellery objects found in Lithuania. Much attention has been paid to the typology and chronology of neck-rings, although these issues have not yet been fully resolved. These ornate neck-rings are jewellery objects made from brass, gunmetal and leaded bronze, and lastly ascribed to type 1, subtypes 2a-c (Bliujienè et al. 2020, Fig. 7, Appendix 2). The trumpet-shaped terminals of this type of neckring are either cast or wrought from metal sheet using the repoussage metalworking technique, and therefore did not need to be joined by riveting or soldering (Bliujienè et al. 2020, Figs. 6 and 7).

The tin sheet soldered and soldering bow is clearly visible on Glaušiai (ascribed to type 1, subtype 2c) neck-rings with hollow trumpet-shaped terminals (Figs. 9.2 and 11). For the soldering, a mixture of tin and lead was used as solder. This is the first such early case of soldering so far found on an artefact in Lithuania. Only three neck-rings of this type and sub-type have been found in the region of their distribution in the east Baltic region, and all were found in Lithuania: one in Glaušiai and the other two in Linkuva (Bliujienè et al. 2020, Appendix 2). Their typological development clearly shows a drift towards the Finno-Ugric area of distribution, where a certain technical degradation of these ornaments was taking place: the neck-rings began to be moulded, and the trumpets of the neck-rings became full-bodied. However, this does not answer the question of their actual place of production and place of manufacture. In terms of manufacturing technique, and the typological variation of these fashionable ornaments, the neck-ring with hollow trumpet-shaped terminals may eventually have been distributed by Sambian-Natangian or travelling jewellers, who were capable of producing such complexshaped items (Bliujiene et al. 2020). The earliest and most technically sophisticated versions of these neck-rings appear in the region of the Lower Nemunas (Vilkų Kampas), in the south of Samogitia (Adakavas and Paragaudis), and in central Lithuania (Glaušiai).

In Lithuania, these neck-rings are found in the graves (as is known from Paragaudis barrow cemetery, see Michelbertas 1989;1997) of people of a high social status, most likely women; or their find circumstances are unknown. Therefore, it is possible that neck-rings with hollow trumpetshaped terminals come from a sacrificial area: offerings in water or from a wealth deposit in the land (see Bliujiene 2010; Oras 2015, pp. 173-195). In Estonia, these neckrings are found in wealth deposits which contain artefacts common to the Balts (Lang 2007, p. 247; Oras 2015). 


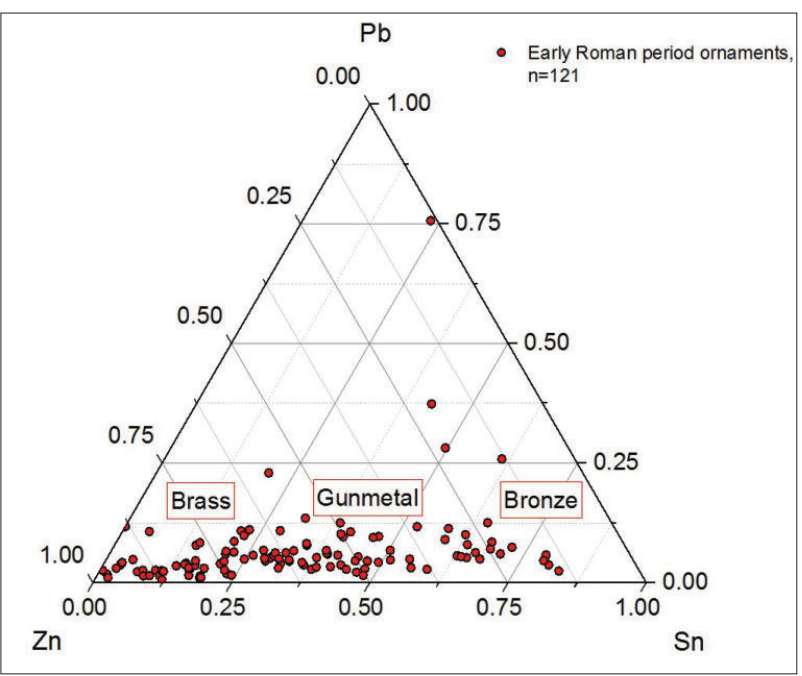

Figure 6. Ternary diagram displaying the $\mathrm{Sn}, \mathrm{Pb}$ and $\mathrm{Zn}$ ratios in alloys of artefacts dating from the Early Roman period $(\mathrm{n}=121)$, according to the classification scheme by Bayley and Butcher (2004, Fig. 5) (diagrams by J. Bagdzevičienè).

\section{Major places and their change}

The density and distribution of the Late Bronze and Earliest Iron Ages artefacts described in this paper, finds of technical ceramics in the hillforts of northeast and east Lithuania, and burial grounds in west Lithuania and the Lower Nemunas area, make it possible to think about certain micro-regions, and to distinguish possible major places where various artefacts could have been manufactured. As was already mentioned above, the disruption to the bronze exchange network in the middle of the 1st millennium, and the spread of iron, changed the range of artefacts used during the Earliest Iron Age. In addition, it is obvious that the previously known burial grounds of west Lithuania and the lower reaches of the Nemunas area disappeared (Figs. 1 and 12). Clearly, there are not enough studied habitation sites excavated using modern methods in this area (Bliujiene et al. 2012; Vengalis et al. 2020). As a result of the rapid changes of settlement structure in the Early Roman period, new sites are emerging.

Meanwhile, in northeast and east Lithuania, some hillforts (e.g. Nevieriškè) were abandoned at the turn of epochmaking changes, and many major centres of the previous period continued to exist (Grigalavičiene 1986a). However, many hillforts were abandoned during the period at the end of the 2nd and the beginning of the 3rd century AD, because people moved to live at the foot of hillforts and unfortified settlements (Lukhtan 2001, pp. 24-26).

One major early centre in west Lithuania could have been in the area between Ėgliškiai, Šlažiai and Šlikiai barrow cemeteries. The Padvariai barrow cemetery, with early agricultural fields and the destroyed Kretingale barrows,

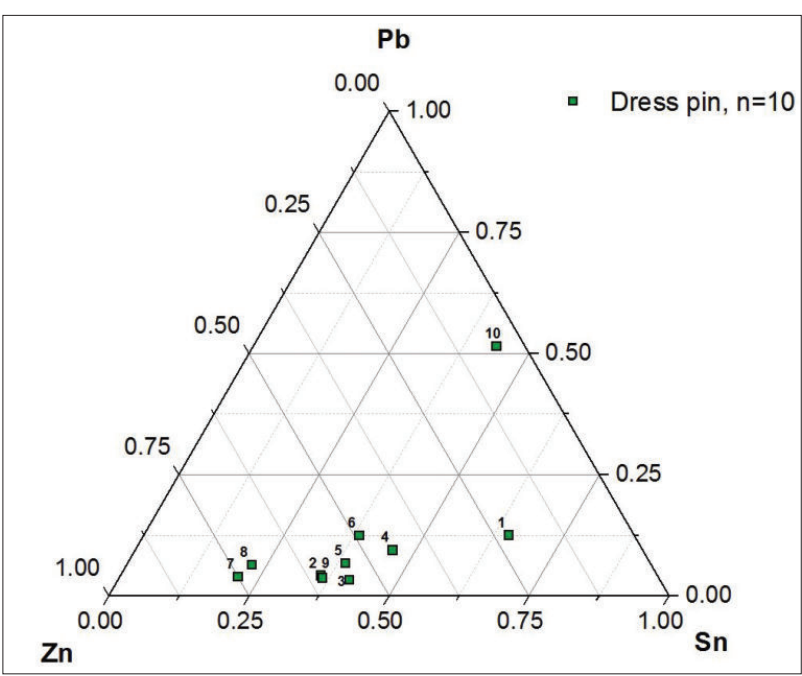

Figure 7. Ternary diagram displaying the $\mathrm{Sn}, \mathrm{Pb}$ and $\mathrm{Zn}$ ratios in alloys of the spool-shaped dress-pins from the Early Roman period, according to the classification scheme by Bayley and Butcher (2004, Fig. 5) (diagrams by J. Bagdzevičienè).

is adjacent to this centre (Merkevičius and Nemickienè 2011, pp. 40-43; Merkevičius 2014, pp. 56-58, 109-114; Muradian 2017). Together with settlements and isolated finds, these burial sites form a fairly compact microregion of the Late Bronze and Earliest Iron Age in the Lithuanian coastal area (Figs. 1 and 12). Finds from inhumation graves in the Ėgliškiai barrow cemetery could have been produced in nearby settlements. This is supported by a 17.4-gram leaded bronze workpiece for a neck-ring or bracelet (barrow 3, grave 3) (Fig. 5.15). A bracelet consisting of 31 leaded bronze rectangular bracelets or rings (total weight over 400 grams, a single bracelet weighs between 13 and 14 grams) is a well-known find from Égliškiai barrow 3, grave 1. This set of bracelets is not a piece of jewellery, but it is possible to say that it is raw material or a leaded bronze ingot in the shape of a ring, and was used for exchange (Fig. 5.14). This statement might be confirmed by the elemental composition of the piece and other jewellery found in the Ėgliškiai barrows and other sites. Sash-like bracelets or rings of different weights have been found in Latvia, Estonia, Scandinavia and Gotland. It is believed that in Scandinavia such artefacts were of a certain weight; therefore, they already measured standardised weight units used in exchange during the Bronze Age (Lang 2007, pp. 118-120).

However, in the Early Roman period, only the Padvariai barrow cemetery still was in function, as an heirloom from the previous time major place at Ėgliškiai surroundings. At Padvariai, barrows contain inhumation burials with eye fibulae and other finds reflecting the Early Roman period (Bliujienè 2013, Fig. 191); whereas burials in the vicinity of the former Ėgliškiai barrows began only in 


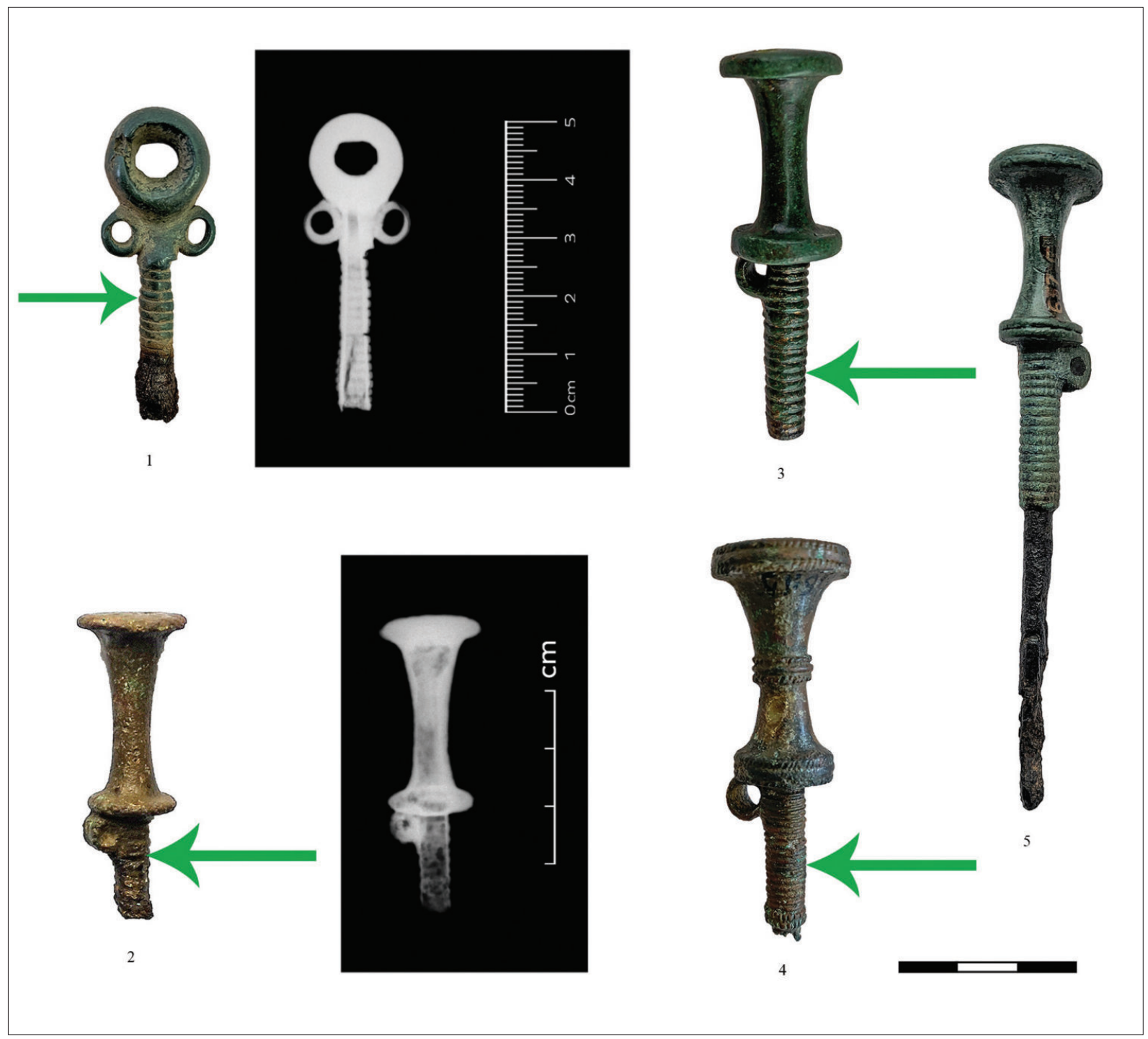

Figure 8. Radiographs showing iron clasp needles embedded in pin heads: 1 . dress pins with wheel-shaped heads with traces of an iron clasp needle (LNM); 2. heads of dress pins with a spool-shaped head and traces of an iron clasp needle inside from Paalksniai barrow cemetery, barrow 9, grave 1 (LNM GRD 68594); 3, 4. heads of dress pins with a spool-shaped head and traces of an iron clasp needle inside from Jagminiške (LNM AR 16:17,15) barrow cemetery. From the J. Obst collection, find circumstances unclear (photographs by A. Bliujiené, radiographs by Rapolas Vedrickas).

the Late Roman period, in Egliškiai-Anduliai cemetery, which is located almost one kilometre southeast of the former barrows.

Earliest Iron Age sites have been found on the right bank of the River Nemunas in central Lithuania, but they do not form important concentrations there (Merkevičius 1994; 2014) (Figs. 1 and 12). However, it is clear that the sites are located along an important transport route, which was to carry people, raw materials and other necessities. In this paper, the region is represented by the Earliest Iron Age burial grounds of Naudvaris and Raudonenai, where spiral temple ornaments made of leaded bronze and bronze were found (Table 1; Fig. 3.1-4; Appendix). Partly due to contacts with Bogaczewo and Sambian-Natangian cul- tures, more sites from the Early Roman period appear in the region of the lower and middle reaches of the Nemunas (Bertašius 2002, pp. 22-23, Fig. 1; Grižas and BitnerWróblewska 2007; Bliujienè 2016). Burial sites then begin to concentrate at the confluences of the rivers Nemunas and Neris, the Nemunas and the Dubysa, and the Nemunas and the Jüra. The area around the confluence of the Nemunas and the Neris, with Sargenai, Kulautuva, Veršvai, Paštuva and Marvelè cemeteries, and some habitation sites, became a particularly important centre during the Early Roman period (Figs. 1 and 12).

During the Earliest Iron Age, one of the sites of nonferrous metal production may have been in the former settlement of Paalksniai in the Samogitian highlands. Burials in the barrow in the area of the settlement began 

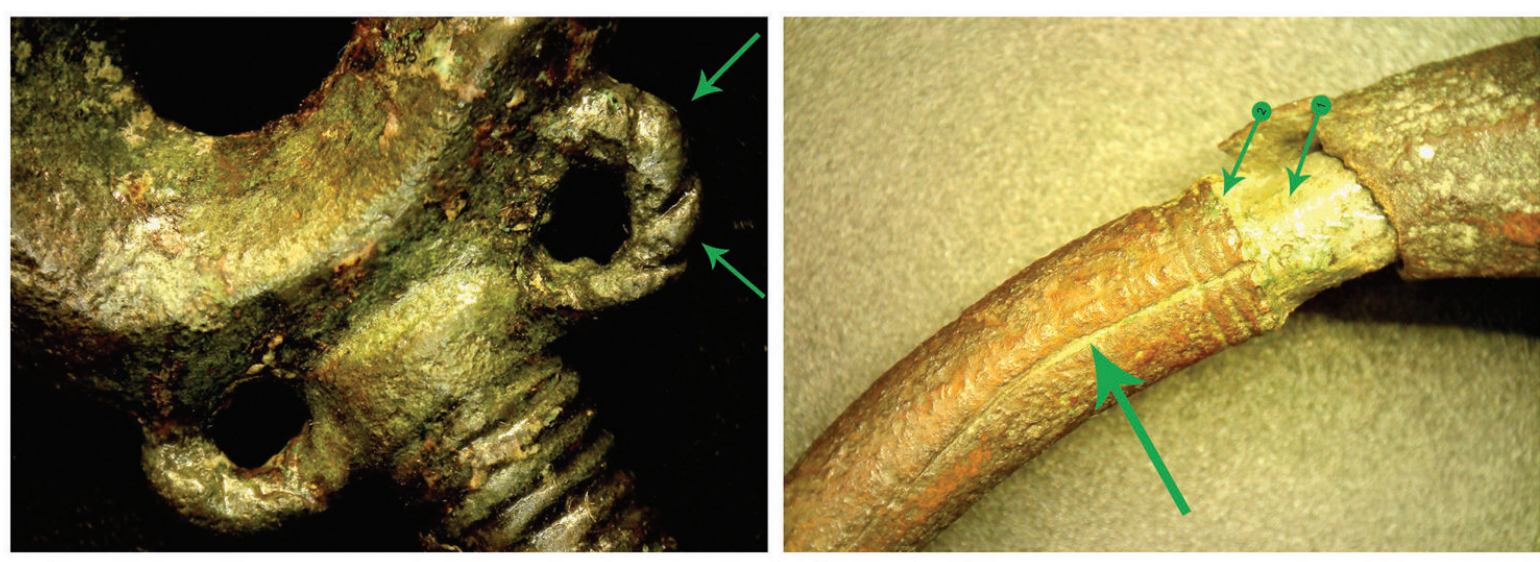

1
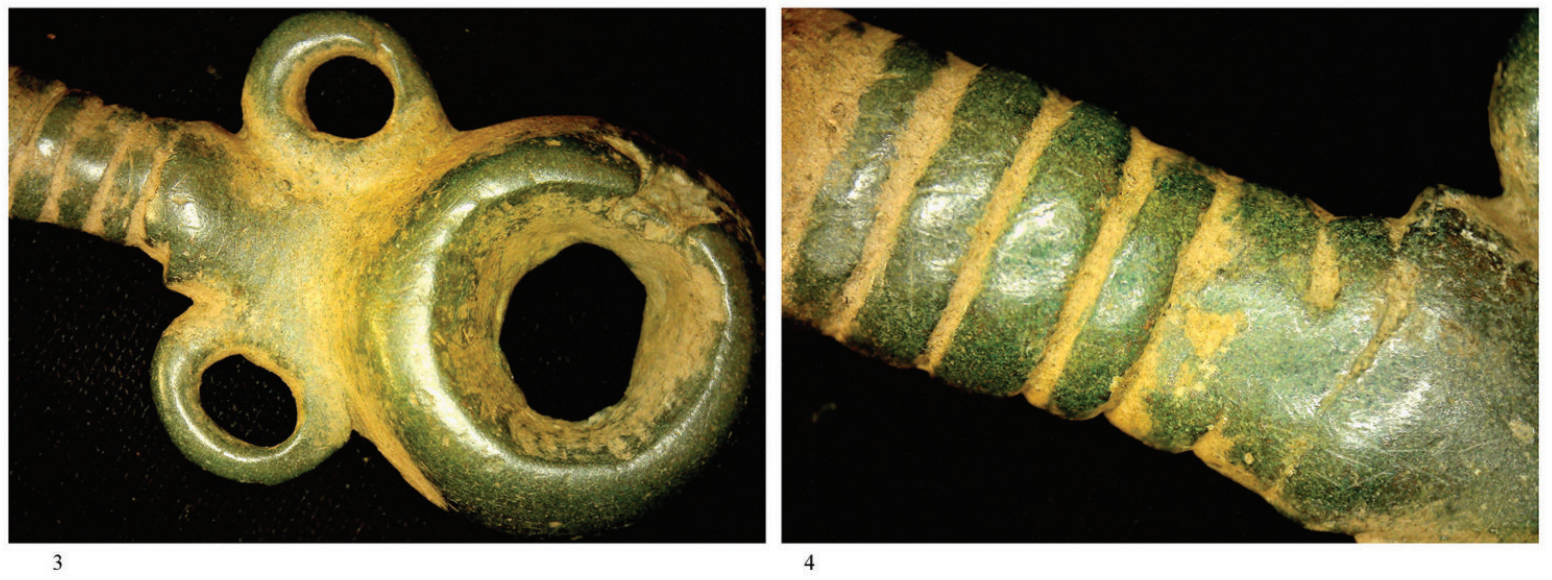

Figure 9. Dress pins with a wheel-shaped head from Ėgliškiai barrow cemetery, barrow 2, grave 1 (LNM AR 636:2); 2. a fragment of a neck-ring bow with hollow trumpet-shaped terminals from Glaušiai cemetery, find circumstances unclear (KMM 830); 3, 4. a dress pin with a wheel-shaped head from Vilūnai site, stray find (LNM). Enlarged 50× (photographs by E. Babenskas).

to take place as early as the second half of the 1st century AD (Michelbertas 2011, pp. 79-80). In the Early Roman period, several barrow cemeteries appeared within the boundaries of the district of Kelme, and, to a certain extent, of Silale, which would indicate that there were some places where non-ferrous metal was worked (Figs. 1 and 12). On the other hand, the picture can be a bit deceptive, as there are many excavated barrow cemeteries in the region. However, production is also partly attested to by the discovery of a hoard of eight copper ingots at the village of Miežaičiai. All 8 ingots were analysed by XRF method. The results show that the ingots were cast from copper alloy with a very high percentage of copper $(\mathrm{Cu}$ is $90-96 \%)$. The zinc and lead in this alloy make up only a small percentage ( $\mathrm{Zn} 1.3-3.1 \%$, Pb 1.4-3.9\%), while Sn was not found. The ingots weighed 247 to 371 grams, one ingot weighing even 611 grams. The elemental composition of the raw material does not contradict that of finds from the Roman and Migration periods.

Although there is little information on Late Bronze Age and Earliest Iron Age finds from southern Lithuania, finds from 2020 suggest that there may also have been centres for the production of particular artefacts, as well as places of regional exchange. One such centre may have been in the vicinity of Vilūnai (Figs. 1 and 10). In addition to the pin found at Vilūnai, two pieces of very poorly preserved leaded bronze alloy bracelets, probably belonging to the Earliest Iron Age, were also found. It is likely that an Earliest Iron Age burial site was located in this area, but due to years of intensive farming activities and infrastructure works around the area, the site may have been completely destroyed. More prehistoric sites were revealed and investigated during further rescue excavations in the construction area of the international gas pipeline at the village of Vilūnai. One such object was the Vilūnai 4 site, where two AMS ${ }^{14} \mathrm{C}$ dates were obtained from a feature resembling the Early and Late Bronze Age in its eastern part. The dates pointed to $1108-919$ cal BC $(2842 \pm 29$; FTMC-YY40-5) and 1625-1502 cal BC (3284 \pm 28 ; FTMC-YY40-6) (Rimkus 2021). However, the dates do not fall into the relative age of the pin fragment, as in the east Baltic its type is ascribed by most authors to the Earliest 


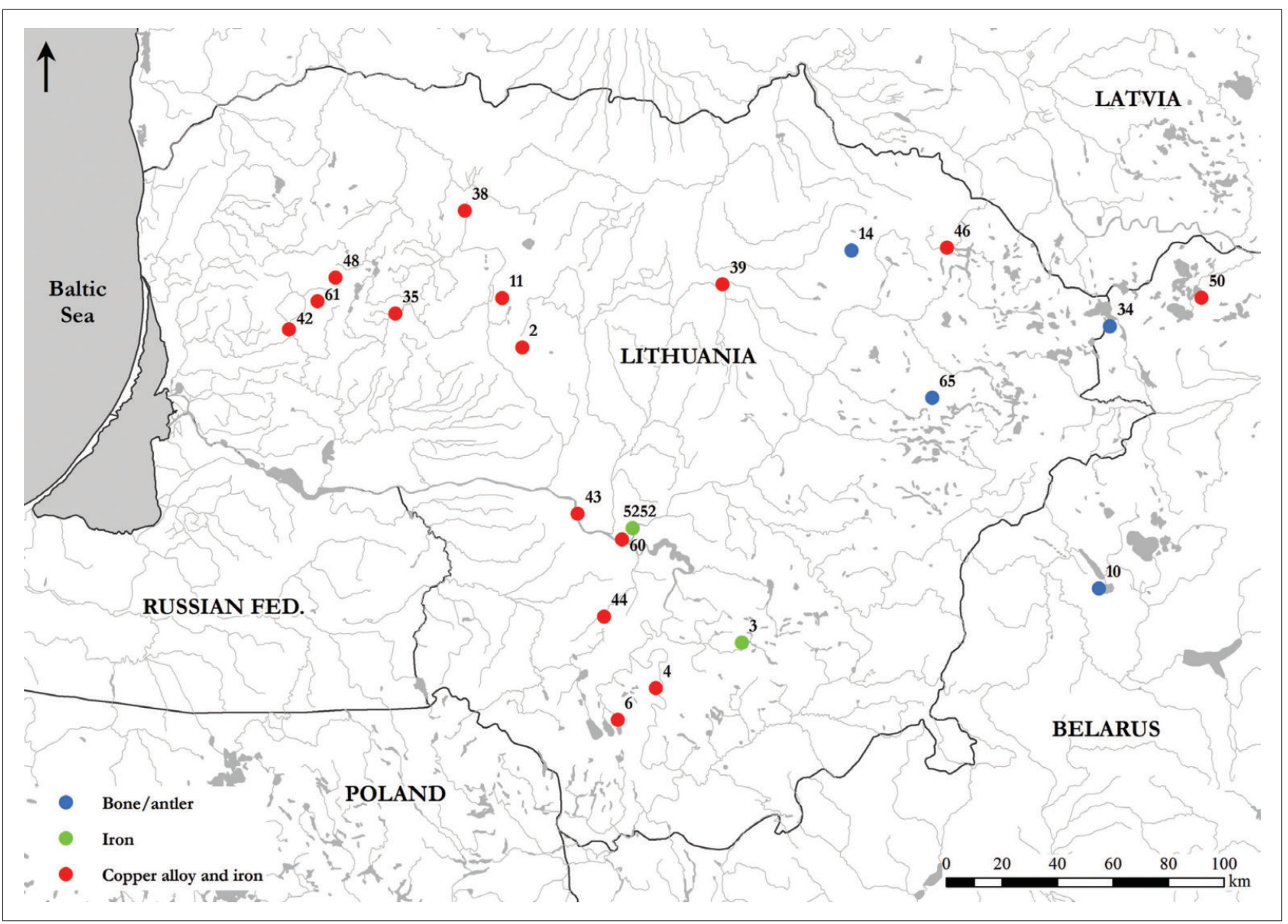

Figure 10. The distribution of spool-head dress pins with pin material marked (according to Tautavičius 1978, Map 41; with new additions by the article authors). For the site numbers on the map, see Appendix (drawing by G.Petrauskas).

Iron Age (Grigalavičienè 1995, p. 185; Merkevičius 2011, pp. 32-33; Girininkas 2013, p. 226). This indicates that the Vilūnai area was inhabited during the Late Bronze Age and Earliest Iron Age, and although the available absolute dates do not coincide with the relative chronology of the pin (see Fig. 3.12), it does not exclude the possibility that there was continuity of occupation in these areas during the Earliest Iron Age. In addition, finds from the Aukštadvaris hillfort and settlement fit the major centres of southeast Lithuania. Based on the settlements of Late Brushed Pottery culture, the Vilūnai and Aukštadvaris centres were still functioning in the Early Roman period (Daugudis 1998) (Figs. 1 and 12).

At Prienlaukis in the Trans-Nemunas region, under unclear circumstances, in the probably disturbed barrow from the Earliest Iron Age, round open-work pendants and pendants of other shapes were found (Grigalavichene 1980, p. 78, Table XXV). Published data from two pendants tested by OES method shows that they are made of brass (Miarkiavichius 1980, Table) (Figs. 1 and 12). This centre seems to extend further, as a Late Roman period spacer ring with red enamel inlay was found in the cen- tre (Michelbertas 2016, p. 80). On the other hand, in the nearby Pažarstis barrows, a massive bracelet with 'knobs', an eye fibula and other finds confirm the existence of the centre in the Early Roman period (Michelbertas 1986, Fig. 60.2; Grižas and Bitner-Wróblewska 2007, p. 263, Figs. 2-6).

In recent years, Late Bronze Age and Earliest Iron Age hillforts in northeast and east Lithuania have yielded both technical ceramics and finds, mostly jewellery (Figs. 1 and 12). However, the question of who produced them remains open, as no concentrated artefact production places have yet been found. Therefore, we must assume that jewellery made of copper alloys was produced locally (Krzywicki 1914; 1917; Luchtanas 1981; 1992; Grigalavičienè 1986b; 1992; Čivilytė 2014; Podėnas et al. 2016; Banytė-Rowell 2017; Luchtanas et al. 2019). The contradiction between the large number of technical ceramic and non-located jewellery workshops discovered can be solved by claiming that production places were short-lived, without the need for specialised equipment. On the other hand, it is likely that the artefacts were made by highly skilled travelling jewellers (Čivilytè 2014; Podènas and Čivilytė 2019). 


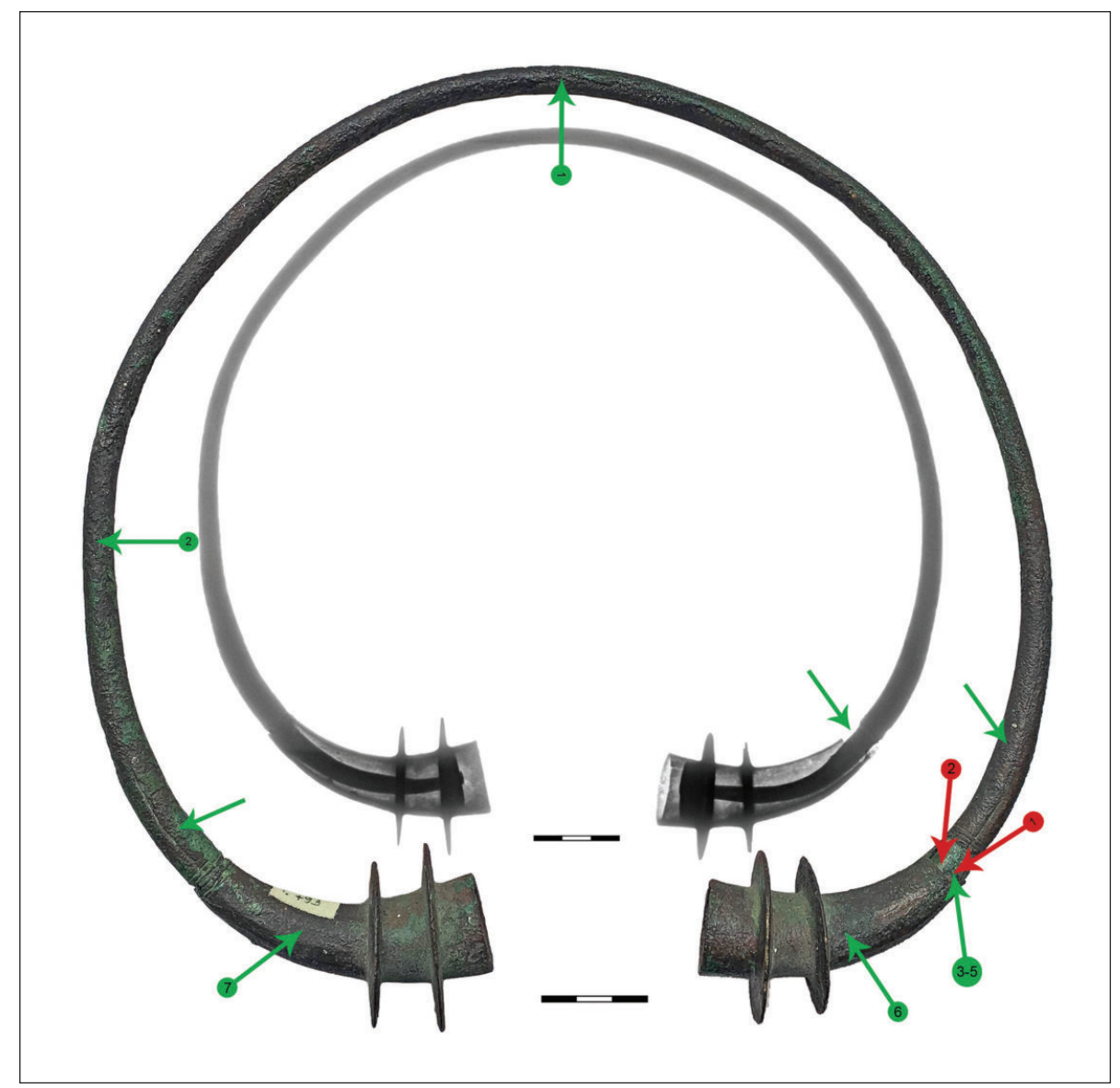

Figure 11. Photograph and radiograph of the neck-ring with hollow trumpet-shaped terminals from Glaušiai (KMM 830) cemetery. Spots investigated by XRF method marked with green arrows; spots of investigated solder are marked with red arrows (photograph by A. Bliujiené, radiograph by R. Vedrickas).

In the Early Roman period, this major centre of hillforts and settlements continued, and probably disintegrated into smaller units, and the leadership of Kernave, with a number of surrounding sites, in east Lithuania prevailed (Figs. 1 and 12).

\section{Conclusions}

Based on the results of X-ray fluorescence (XRF) spectrometry studies on Lithuanian archaeological material, it was found that artefacts from the Late Bronze Age to the Earliest Iron Age were made of bronze and leaded bronze. However, there is no essential difference in the composition of the copper alloys used between east and west Lithuania. Nevertheless, there was a slight difference in the composition of copper alloys used in east and west Lithuania during this period. The alloys from the western part are more homogeneous. Towards the end of the Earliest Iron Age, brass-like alloys appeared among the copper alloys used. At the end of the Earliest Iron Age, in addition to casting, the number of artefacts produced from hammered wire and thin tin sheets increased. Technically, malleable brass was most suitable for the production of artefacts by forging. Thus, the change in the elemental com- position of copper alloy may have been due to the greater variety of artefacts produced in the east Baltic region at the end of the Earliest Iron Age. The change in alloy, on the other hand, was a European trend that reached northeast Europe fairly quickly. However, the main change in the composition of copper alloys took place during the transition from the Earliest Iron Age to the Early Roman period.

Alloys and/or scrap metal used to reach present-day Lithuania through a long and complex chain of exchange, using different exchange equivalents. The elemental composition of copper alloys in artefacts dated to the Late Bronze and the Earliest Iron Ages, and the Early Roman period followed the same tendencies as in other European regions.

The process of change in the elemental composition of copper alloys in the Early Roman period was accompanied by the rapid development of high-production technologies, with the emergence of finds produced by highly sophisticated manufacturing and processing techniques that could only be mastered by jewellers who were able to use multiplex technologies. The technologies of the Earliest Iron Age and the Early Roman period have been characterised by means of radiographic and micro-chemical 


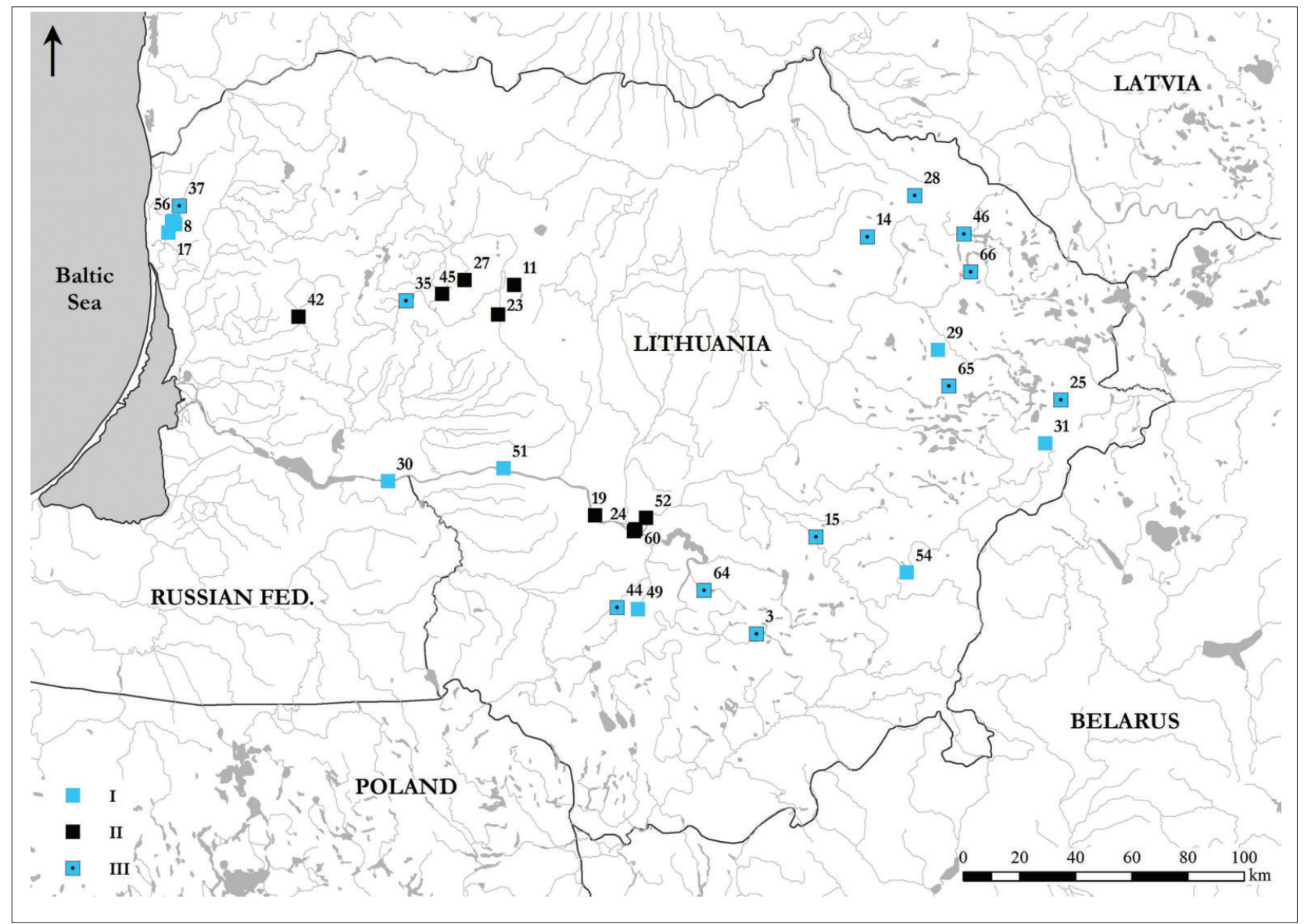

Figure 12. Possible major sites:

I. In the Bronze and Earliest Iron Ages; II. In the Early Roman Period; III. In the Earliest Iron Age and the Early Roman Period. For the site numbers on the map, see Appendix (drawing by G. Petrauskas).

qualitative analysis, and by means of magnification studies of the finds. It is therefore likely that this role was played by itinerant jewellers, based on contemporaneous monuments and the distribution of artefacts in distinct major centres. The sudden jump in the settlement structure has allowed for the identification of new production techniques, jewellery-making skills, production sites, and to some extent, changes in the direction of exchange.

\section{Acknowledgements}

This study was supported by the Research Council of Lithuania under grant number S-MIP-19-50. We are grateful to the National Museum of Lithuania, the Vytautas the Great War Museum, the State Cultural Reserve of Kernave and the Kedainiai Regional Museum for access to the artefacts used in our study. We sincerely thank our colleague Dr. Gintautas Zabiela for sharing not published material of Vilūnai site. We would also like to thank Asta Vasiliauskaite for her help in studying artefacts held in the Vytautas the Great War Museum, Dr Laima Grabauskaite for instrumental studies of archaeological material, and Dr Egidijus Šatavičius for his valuable comments on the function of bone finds from Vorènai.

\section{Appendix}

Sites mentioned in the text (see Fig. 1). The site numbers correspond to the numbers on all maps in the article.

1. Adakavas (Tauragè district).

2. Akmenè (Sandrausiškè) (Raseiniai district).

3. Aukštadvaris (Trakai district).

4. Bakšiai (Alytus city).

5. Batakiai (Tauragè district).

6. Cigoniškiai (Alytus district).

7. Dauglaukis (Taurage district).

8. Ėgliškiai (Kretinga district).

9. Glaušiai (Kèdainiai district).

10. Gorani (Smarhon district, Belarus).

11. Jagminiškè (Kelmė district)

12. Jonelaičiai (Šiauliai district).

13. Kegai (Telšiai district).

14. Kereliai (Kupiškis district).

15. Kernavė (Širvintos district). 
16. Kybartiškè (Šiauliai district).

17. Kretingalè (Klaipèda district).

18. Kukiai (Petreliai) (Mažeikiai district).

19. Kulautuva (Kaunas district).

20. Kurmaičiai (Kretinga district).

21. Linksmènai (Kurmaičiai) (Joniškis district).

22. Linkuva (Pakruojis district).

23. Maironiai (Saudininkai) (Kelmė district).

24. Marvelè (Kaunas city).

25. Mažulonys (Ignalina district).

26. Medvėgalis (Karūžiškè) (Šilalè district).

27. Miežaičiai (Kelmè district).

28. Moškènai (Laukupėnai) (Rokiškis district).

29. Narkūnai (Utena district).

30. Naudvaris (Jurbarkas district).

31. Nevieriškè (Švenčionys district).

32. Nikèlai (Šilutė district).

33. Noliškiai (Šiauliai district).

34. Nurviany (Braslav district, Belarus).

35. Paalksniai (Kelmè district).

36. Pabaliai (Joniškis district).

37. Padvariai (Kretinga district).

38. Padvarninkai (Šiauliai district).

39. Pajuostis (Panevéžys district).

40. Pajūralis (Skerdynai) (Šilalè district).

41. Papilys (Skomantai) (Klaipéda district).

42. Paragaudis (Šilalè district).

43. Paštuva (Kaunas district).

44. Pažarstis (Prienai district).

45. Perkūniškè (Kelmė district).

46. Petrešiūnai (Rokiškis district).

47. Pilviškès (Vilnius district).

48. Pribitka (Rietavas municipality).

49. Prienlaukys (Prienai district).

50. Ratiunki (Braslav district, Belarus).

51. Raudonènai (Jurbarkas district).

52. Sargènai (Kaunas city).

53. Sokiškiai (Ignalina district).

54. Staviškès (Vilnius city).

55. Strazdai (Ječiškès) (Pagėgiai municipality).

56. Šlažiai (Kretinga district).

57. Šlikiai (Klaipèda district).

58. Telšiai (Telšiai district).

59. Velikuškès (Zarasai district).

60. Veršvai (Kaunas city).

61. Vienragiai (Rietavas municipality).

62. Vilkija (Kaunas district).

63. Vilkų Kampas (Šilutė district).

64. Vilūnai (Kaišiadorys district).

65. Vorènai (Molètai district).

66. Vosgèliai (Zarasai district).

67. Zastaučiai (Mažeikiai district).

\section{Abbreviations}

Lietuvos arch. - Lietuvos archeologija

Archaeol. Balt. - Archaeologija Baltica

Arch. Lituana - Archaeologia Lituana

\section{References}

\section{Manuscripts}

Rimkus, T., 2021. Vilūnu senovès gyvenvietés, Kaišiadoriu r. sav., Kruonio sen., dujotiekiu jungties tarp Lenkijos ir Lietuvos (GIPL) vietoje $2020 \mathrm{~m}$. detaliuju archeologiniu tyrimy ataskaita. T. III. Klaipeda. Unpublished excavation report, Institute of Baltic Region History and Archaeology library, archive no. 903/904 (474.5), file no. Ri-85.

\section{Literature}

Almgren, O., 1923. Studien über Nordeuropäische Fibelformen der ersten nachchristlichen Jahrhunderte, mit Berücksichtigung der provinzialrömischen und südrussischen Formen. Stockholm: Druck von I. Haeggström.

Andrzejowski, J., 1998. Nadkole 2. A Cemetery of the Przeworsk Culture in Eastern Poland. In: Monumenta Archaeologica Barbarica, V. Kraków: Secesja.

Bayley, J., Butcher, S., 2004. Roman Brooches in Britain: A Technological and Typological Study Based on the Richborough Collection. London: The Society of Antiquaries of London.

Banyte-Rowell, R., 2017. Searching for Links Between Artefacts from Areas of Prehistoric Dwelling and Burial Grounds. Lietuvos arch., 43, 87-114.

Beckmann, B., 1969. Die baltischen Metallnadeln der römischen Kaiserzeit. Saalburg Jahrbuch, XXVI, 107-119.

Bertašius, M., 2002. Vidurio Lietuva VIII-XII a. Kaunas: Vytauto Didžiojo universitetas.

Bliujienè, A., 2010.The Bog Offerings of the Balts: 'I Give in Oder to Get Back'. Archaeol. Balt., 14, 136-165.

Bliujienè, A., 2013. Romeniškasis ir tautu kraustymosi laikotarpiai. In: Lietuvos archeologija, t. III. Klaipèda: Klaipèdos universiteto leidykla.

Bliujienè, A., 2016. South Lithuanian Barrows. In: G. Zabiela, Z. Baubonis, E. Marcinkevičiūte, eds. A Hundred Years of Archaeological Discoveries in Lithuania. Vilnius: Lietuvos archeologijos draugija, pp. 208-225.

Bliujienè, A., Stančikaitè, M., Kisielienè, D., Mažeika, J., Taraškevičius, R., Szwarczewski. P., Messal, S., Kusiak, J,Stakeniené, R., 2012. Skomantai Hill-Fort in Western Lithuania: The Case Study on Habitation Site and Environment. Archaeol. Balt., 17, 101-135. https://doi.org/10.15181/ ab.v17i0.55

Bliujienė, A., Petrauskas, G., Bagdzevičienè, J., Suzdalev, S., Babenskas, E., 2020. Early Roman Iron Age Jewellery in the Northern Barbaricum: Between Stylistic and Technological Simplicity and Luxury. In: M.R. Galan, R.S. Bard, eds. Studies in Archaeometry. Proceedings of the Archaeometry Symposium at NORM 2019, June 16-19, Portland, Oregon, Portland State University. Dedicated to the Rev. H. Richard Rutherford, C.S.C., Ph.D. Oxford: Archaeopress publishing, pp. 175-217.

Bliujene,, A., Peseckas, K., Šapolaitè, J., Ežerinskis, Ž., Bagdzevičienè'J., Babenskas, E., Taraškevičius, R., Suzdalev, S., Vybernaitè-Lubiene, I., Pabedinskas, A., Butkus, L., Petrauskas, G., 2021. Manufacture of the Well-known Central and North-Eastern European Eye Fibulae: Previously Unknown 
Tricks of the Trade. Radiocarbon, 63 (5), 1369-1386. https:// doi.org/10.1017/RDC.2021.69

Brazaitis, Dž., 2005. Ankstyvasis metalų laikotarpis. In: A. Girininkas, ed. Lietuvos istorija t. I. Akmens amžius ir ankstyvasis metalu laikotarpis. Vilnius: Baltos lankos, pp. 253-323.

Chernykh, E.N., 2002. Kargaly. Geological and Geographical Characteristics Exploitation and History of Discoveries: Archaeological Sites, I. Moscow.

Chubur, A.A., 2012. Bulavki c azhurnym listovidnym navershiem v rannem zheleznom veke vostochnoĭ Evropy: tipologiia, areal, semantika. Materialy i issledovaniia po arkheologii Dneprovskogo Levoberezh'ia, IV, 117-135.

Craddock, P.T., 1978. The Composition of the Copper Alloys Used by the Greek, Etruscan and Roman Civilizations: 3. The Origins and Early Use of Brass. Journal of Archaeological Science, 5 (1), 1-16. https://doi.org/10.1016/0305-4403(78)900158

Craddock, P.T., Eckstein, K., 2003. Production of Brass in Antiquity by Direct Reduction. In: J. Lang, P.T. Craddock, eds. Mining and Metal Production through the Ages. London: British Museum, pp. 216-230.

Čivilytė, A., 2014. Žmogus ir metalas priešistorejje: žvilgančios bronzos trauka. Vilnius: Diemedis.

Daugudis, V., 1998. The Aukštadvaris Hill-fort. In: A. Kuncevičius, E. Jovaiša, V. Šimenas, eds. Lithuanian Archaeology: Investigations and Findings. Vilnius: Lietuvos archeologijos draugija, p. 20.

Dungworth, D.B., 1997. Roman Copper Alloys: Analysis of Artefacts from Northern Britain. Journal of Archaeological Science, 24 (10), 901-910. https://doi.org/10.1006/jasc.1996.0169

Egoreĭchenko, A., 2006. Kul'tury shtrikhovannol keramiki. Minsk: Belarusski gosudartveny universitet.

Gan, P., 2015. Charakterystyka chemiczna zabytków z cmentarzyska w Czarnówku - analizy wprowadzajace. In: J. Andrzejowski, ed. Czarnówko, stan. 5. Cmentarzyska z późnej starożytności na Pomorzu 1 (Monumenta Archaeologica Barbarica. Series Gemina V). Lębork-Warszawa: Muzeum w Lęborku, Fundacja Monumenta Archaeologica Barbarica, pp. 175-214.

Girininkas, A., 2013. Ankstyvasis metaly laikotarpis. In: Lietuvos archeologija, t. II. Klaipèda: Klaipedos universiteto leidykla.

Grigalavičienė, E., 1979. Ėgliškių pilkapiai. Lietuvos arch., 1, 5-43.

Grigalavičiene, E., 1986a. Nevieriškès piliakalnis. Lietuvos arch., $5,52-88$

Grigalavičienè, E., 1986b. Sokiškių piliakalnis. Ignalinos raj., Sokiškių apyl. Lietuvos arch., 5, 89-137.

Grigalavičienè, E., 1992. Kerelių piliakalnis. Lietuvos arch., 8, 85-105.

Grigalavičienè, E., 1995. Žalvario ir ankstyvasis geležies amžius Lietuvoje. Vilnius: Mokslo ir enciklopedijų leidykla.

Grigalavichene, E., 1980. Drevneǐshie metallicheskie izdeliia v Litve. In: E. Grigalavichene, A. Miarkiavichius, eds. Drevneǐshie metallicheskie izdeliia $v$ Litve (II-I tysiacheletiia do n.e.). Vilnius: Mokslas, pp. 3-100.

Grižas, G., Bitner-Wróblewska, A., 2007. Ceramika kultury bogaczewskiej z południowej Litwy. In: A. Bitner-Wróblewska, ed. Kultura bogaczewska w 20 lat później. Materiały z konferencji, Warszawa, 26-27 marca 2003. Seminarium Bałtyjskie, I. Warszawa: Państwowe Museum Archeologiczne w Warszawe, pp. 261-278.

Hammer, P., Voß, H.-U., 2011. Aussagen der elektrischen Leitfähigkeit zu Legierung und Herstellung von Fibeln und Gefäßteilen. In: M. Mączyńska ed. Der frühvölkerwanderungszeitliche Hortfund aus Eubiana, Kreis Kościerzyna (Pommern), Bericht der Römisch-Germanischen Kommission, 90, pp. 200-229.
Heginbotham, A., Bassett, J., Bourgarit, D., Eveleigh, C., Glinsman, L., Hook, D., Smith, D., Speakman, R.J., Shugar, A., van Langh, R., 2015. The Copper CHARM Set: A New Set of Certified Reference,Materials for the Standardization of Quantitative X-ray Fluorescence analysis of Heritage Copper Alloys. Archaeometry, 57 (5), 856-868. https://doi. org/10.1111/arcm.12117

Jaanits, L., Laul, S., Lõugas, V., Tõnisson, E., 1982. Eesti esiajalugu. Tallinn: Eesti Raamat.

Jouttijärvi, A., 2009. Roman Metal Votives from Denmark. Materials and Manufacturing Processes, 24 (9), 1007-1014. https:// doi.org/10.1080/10426910902987465

Jouttijärvi, A., 2017. Roman Alloying Practice. Materials and Manufacturing Processes, 32 (7-8), 813-826. https://doi.org/1 $\underline{0.1080 / 10426914.2017 .1279325}$

Jovaiša, E., 2020. Kapai ir žmonès. Aisčiai, romenai, gotai ir kitos istorijos. Vilnius: Unseen Pictures.

Juga-Szymańska, A., 2014. Kontakty Pojezierza Mazurskiego ze wschodniq strefa Battyku w okresie wplywów rzymskich na przykładzie szpil. In: Państwowe Muzeum Archeologiczne Seminarium Bałtyjskie, Vol., III. Warszawa: Fundacija Monumenta Archeologica Barbarica, Państwowe Museum Archeologiczne w Warszawe.

Kliaugaitė, V., 2006. Mažulonių piliakalnio papèdès gyvenvietė. In: Archeologiniai tyrinejimai Lietuvoje 2005 metais. Vilnius, Lietuvos archeologijos draugija, pp. 29-30.

Kulikauskienè, R., Rimantienė, R., 1958 (eds.). Lietuviu liaudies menas. Senovés lietuviu papuošalai, I knyga. Vilnius: Valstybinè grožinès literatūros leidykla.

Krzywicki, L., 1914. Piłkalnia pod wsią Petraszunami. Rocznik Towarzystwa Przyjaciół Nauk w Wilnie 5 (1911-1914), 1-27.

Krzywicki, L., 1917. Grodziska górno-litewskie. Grodzisko na Górze Ościkowej pod Rakiszkami. Warszawa.

Kuzminykh, S.V., 1983. Metallurgia Volgo-Kam'ia v rannem zheleznom veke. Med' i bronza. Moskva.

Lang, V., 2007. The Bronze and Early Iron Ages in Estonia. In: Estonian archaeology, Vol. 3. Tartu: Tartu University Press.

Luchtanas A., 1981. Žalvario apdirbimas ankstyvuosiuose rytų Lietuvos piliakalniuose. Lietuvos arch., 2, 5-17.

Luchtanas, A., 1992. Rytų Lietuva I tūkst. pr. m. erą. Lietuvos arch., 5, 56-83.

Luchtanas, A., 1998. Ankstyvojo geležies amžiaus Kernavès kapinynas. Lietuvos arch., 9, 35-39.

Lukhtan, A., 2001. K voprosu ob ischeznovenii kul'tury shtrikhovannoĭ keramiki v baseinne Neris (gorodicha i selicha v Kiarnave). Arch. Lituana, 2, 22-28.

Luchtanas, A., Sidrys, R.V., 1999. Bronzos plitimas rytiniame Pabaltijo regione. Arch. Lituana, 1, 15-55.

Luchtanas A., Podènas, V., Babenskas, E., 2019. Romèniškojo laikotarpio ritinis smeigtukas: nuo archeologinio radinio iki rekonstrukcijos=Spool-headed Pin from the Roman Period: From Archeological Find to Reconstruction. In: D. Luchtanienè, ed. Eksperimentine archeologija. Lietuvos materialaus paveldo rekonstrukcija=Experimental Archaeology. Reconstruction of Material Heritage of Lithuania, t. III. Vilnius: Akademikai, pp. 9-43.

Łuczkiewicz, P., Gan, P., Kuzioła, A, Kleemann, J., 2022 (in press). Contribution to the Metallurgy Research: Remarks Based on the Chemical Composition Analyses of the Eye Brooches of the Prussian Series from the Burial Ground in Malbork-Wielbark. Sprawozdania Archeologiczne.

Merkevičius, A., 1973. Seniausiujjų Lietuvos metalo dirbinių cheminè sudètis. Lietuvos TSR mokslu akademijos darbai, serija $A, 43$ (2), 87-102.

Merkevičius, A., 1986. Narkūnų piliakalnio spalvotojo metalo dirbiniai. Lietuvos arch., 5, 49-52. 
Merkevičius, A., 1994. Etnokultūrinè situacija laidosenos duomenimis Vidurio Lietuvoje žalvario ir ankstyvajame geležies amžiuje. In: A. Astrauskas, ed. Vidurio Lietuvos archeologija. Konferencijos medžiaga $1994 \mathrm{~m}$. Vilnius: VU Archeologijos Katedra, Marvelès Ekspedicija, pp., 5-9.

Merkevičius, A., 2011. Ankstyvieji metaliniai dirbiniai Lietuvoje. Vilnius: Vilniaus universiteto leidykla.

Merkevičius, A., Nemickienè, R., 2011. Senieji laukai Šiaurès vakaru Lietuvoje. Vilnius: Vilniaus universiteto leidykla.

Miarkiavichius, A., 1980. Khimicheskiŭ sostav drevneŭshikh bronzovykh izdeliĭ na teritorii Litvy. In: E. Grigalavichene,A. Miarkiavichius, eds. Drevneı̌shie metallicheskie izdeliia $v$ Litve (II-I tysiacheletiia do n.e.). Vilnius: Mokslas, pp.101-113.

Michelbertas, M., 1986. Senasis geležies amžius Lietuvoje I-IV amžius. Vilnius: Mokslas.

Michelbertas, M., 1989. Antkaklių trimitiniais galais (III gr.) chronologijos klausimu. Lietuvos arch., 9, 127-132.

Michelbertas, M., 2010. Unikalus radinys Paalksnių (Kelmès r.) pilkapyne. In: G. Blažienè, S. Grigaravičiūtè, A. Ragauskas, eds. Florilegium Lithuanum. In honorem eximii professoris atque academici Lithuani domini Eugenii Jovaiša anniversarii sexagesimi causa dicatum. Vilnius: Vilniaus pedagoginio universiteto leidykla, pp. 61-66.

Michelbertas, M., 2011. Paalksniu archeologijos paminklai. Vilnius: Vilniaus universiteto leidykla.

Michelbertas, M., 2016. Romenniškojo laikotarpio emaliuoti dirbiniai Lietuvoje. Vilnius: Vilniaus universiteto leidykla.

Minkevičius, K., Podènas, V., Urbonaitė-Ubė, M., Ubis, E., Kisieliene, D., 2020. New Evidence on the Southeast Baltic Late Bronze Age Agrarian Intensification and the earliest AMS Dates of Lens culinaris and Vicia faba. Vegetation History and Archaeobotany, 29, 327-338. https://doi.org/10.1007/s00334019-00745-2

Muradian, L., 2017. Vèlyvojo žalvario ir ankstyvojo geležies amžiaus laidosena ir visuomenè Šiaurès vakarų Lietuvoje. Arch. Lituana, 18, 47-77. https://doi.org/10.15388/ArchLit.2017.18.11689

Pauli, M., 2019. Die sog. preußischen Augenfibeln aus Augsburg - Zeugnisse germanischer Fibelschmiede in der raetischen Provinzhauptstadt? Colloquium Biricianis 2019. Kernprovinz - Grenzraum - Vorland. Kontakte und Strukturen vom 1. Jh. v. bis zum 6. Jh. n. Chr. im. Bereich von Raetien, Noricum und benachbarten Gebieten. Weißenburg in Bayern.

Pietrzak, M., 1997. Pruszcz Gdański. Fundstelle 10. Ein Gräberfeld der Oksywie- und Wielbark-Kultur in Ostpommern (Monumenta Archaeologica Barbarica IV). Kraków: Secesja.

Piličiauskas, G., Vengalis, R., Minkevičius, K., Kisielienè, D., Ežerinskis, Ž., Šapolaitė, J., Skipitytė, R.,Robson, H.K., 2021. The Earliest Evidence for Crop Cultivation During the Early Bronze Age in the Southeastern Baltic. Journal of Archaeological Science: Reports, 36, 102881. https://doi.org/10.1016/j.jasrep.2021.102881

Podenas, V., 2020. Emergence of Hilltop Settlements in the Southeastern Baltic: New AMS ${ }^{14} \mathrm{C}$ Dates from Lithuania and Revised Chronology. Radiocarbon, 62 (2), 361-377. https:// doi.org/10.1017/RDC.2019.152

Podėnas, V., Čivilytè, A., 2019. Bronze Casting and Communication in the Southeastern Baltic Bronze Age. Lietuvos arch., 45, 169-199. https://doi.org/10.33918/25386514-045005

Podènas, V., Čivilytė, A., Bagdzevičienè, J., Luchtanas, A., 2016. Technologiniai ir diagnostiniai Narkūnų techninės keramikos tyrimai. Lietuvos arch., 42, 151-189.

Pollard, A.M., Bray, P., Gosden, C., Wilson, A., Hamerow, H., 2015. Characterising Copper-Based Metals in Britain in the
First Millennium AD: A Preliminary Quantification of Metal Flow and Recycling. Antiquity, 89 (345), 697-713. https://doi. org/10.15184/aqy.2015.20

Pollard, A.M., Bray, P., Cuénod, A., Hommel, P., Hsu, Y.-K., Liu, R., Perucchetti, L., Pouncett, J., Saunders, M., 2018. Beyond Provenance. New Approaches to Interpreting the Chemistry of Archaeological Copper Alloys (Studies in Archaeological Sciences 6). Leuven: Leuven University Press.

Oras, E., 2015. Practices of Wealth Depositing in the $1^{\text {st }}-9^{\text {th }}$ Century AD Eastern Baltic. Leiden: Sidestone Press.

Radivojević, M., Roberts, B.W., Pernicka, E., Stos-Gale, Z., Martinón-Torres, M., Rehren, T., Bray, P., Brandherm, D., Ling, J., Mei, J., Vandkilde, H., Kristiansen, K., Shennan, S.J. Broodbank, C., 2018. The provenance, use and circulation of metals in the European Bronze, Age: the state of debate. Journal of Archaeological Research, 27, 131-185. https://doi.org/10.1007/ s10814-018-9123-9

Roxburgh, M., Heeren, S., Huisman, H.,van Os, B. 2016. Early Roman Copper-alloy Brooch Production: A Compositional Analysis of 400 Brooches from Germania Inferior. Journal of Roman Archaeology, 29, 411-421. https://doi.org/10.1017/ S1047759400072202

Rzeszotarska-Nowakiewicz, A., 2010. Neckrings with Trumpetshaped Terminals (mit Trompetenenden) - Some Remarks on Traces of Contacts in the Baltic Basin during the Early Roman Period. In: U. Lund Hansen, A. Bitner-Wróblewska, eds. Worlds Apart? Contacts across the Baltic Sea in the Iron Age.. København-Warszawa: Det Kongelige Nordiske Oldkriftselskab pp. 315-336.

Shpilev, A.G., 2018. Novye nakhodki bulavok c azhurnymi navershiiami épokhi rannego zheleznogo veka iz Kurskoĭ oblasti. Materialy i issledovaniia po arkheologii Dneprovskogo Levoberezh'ia, V, 38-46.

Stos-Gale, Z.A., 2017. Possibilities and limitations of interpretation of the results of lead isotope and elemental compositions of copper-based alloys dated to the Later Roman period (c. 2nd-4th c.) from Jakuszowice, southern Poland. Powerpoint presentation (received from the author).

Stos-Gale, Z.A., 2019. Analizy izotopow ołowiu a pochodzenie znalezisk $\mathrm{z}$ brązu $=$ Lead Isotopes and the Origin of Bronze Artefacts. In: J. Sobieraj, ed. Początki epoki brązu na Warmii i Mazurach $w$ świetle analiz specjalistycznych=The Origins of the Bronze Age in Warmia and Masuria Revealed by Scientific Analyses. Olsztyn: Muzeum Warmii i Mazur, pp. 83-118.

Šiaulinskas, R., 2016. The Lower Nemunas during the Early Metal Age. In: G. Zabiela, Z. Baubonis, E. Marcinkevičiūte, eds. A Hundred Years of Archaeological Discoveries in Lithuania. Vilnius: Lietuvos archeologijos draugija, pp. 120-129.

Tautavičius, A. (ed.) 1978. Lietuvos TSR Archeologijos Atlasas. IXIII a. radiniai. t. IV. Vilnius.

Vaitkunskiené, L., Merkevičius, A., 1978. Spalvotuju metalu dirbiniai ir jų gamyba. In: R. Volkaitè-Kulikauskienè, ed. Lietuviu materialine kultūra IX-XIII amžiuje, t. I. Vilnius: Mokslas, pp. 89-118.

Vasks, A., 2010. Latvia as Part of a Sphere of Contacts in the Bronze Age. Archaeol. Balt., 13, 153-161.

Vengalis, R., Piličiauskas, G., Pilkauskas, M, Kozakaite, J., ,Juškaitis, J., 2020. The Large-Scale Rescue Excavation of a Multi-Period Site at Kvietiniai Sheds Light on the so Far Little Explored Bronze Age in Western Lithuania. Archaeol. Balt., 27, 17-50. https://doi.org/10.15181/ab.v27i0.2176

Volkaitè-Kulikauskienè, R., 1986. Narkūnų didžiojo piliakalnio tyrimų rezultatai (apatinis kultūrinis sluoksnis). Lietuvos arch., 5, 5-49. 
ESMINIAI VARIO LYDINIŲ

SUDÉTIES POKYČIAI, ATSKLEIDŽIANTYS

TECHNOLOGINIUS SKIRTUMUS, PEREINANT IŠ ANKSTYVOJO

GELEŽIES AMŽIAUS I

ANKSTYVĄJt ROMÉNIŠKĄJt

LAIKOTARPI LIETUVOJE
9:2; 10; 11 pav.; 2, 3 lent.), todèl tikètina, kad jie gaminti keliaujančių juvelyrų. Staigus apgyvendinimo struktūros šuolis, naujoviškai pagamintų dirbinių atsiradimas ir paplitimas leidžia nustatyti atsiradusius gamybos centrus ir iš dalies pasikeitusias mainų kryptis (11 pav.).

\section{AUDRONE் BLIUJIENE், GEDIMINAS PETRAUSKAS, JURGA BAGDZEVIČIENĖ, EVALDAS BABENSKAS, TOMAS RIMKUS}

\section{Santrauka}

Remiantis Lietuvos archeologinès medžiagos rentgeno fluorescencijos (XRF) spektrometrijos tyrimų rezultatais, nustatyta, kad nuo vèlyvojo bronzos amžiaus iki ankstyvojo geležies amžiaus dirbiniai buvo gaminti iš bronzos ir švino bronzos (2; 3; 5 pav.; 1 lent.). Ankstyvajame geležies amžiuje nèra esminio skirtumo tarp vario lydinių naudotų Rytų ir Vakarų Lietuvoje, elementinès sudèties. Tačiau vis dèlto vakarinejje dalyje naudotų lydinių elementinè sudètis homogeniškesnè už naudotų rytinèje Lietuvoje dalyje. Ankstyvojo geležies amžiaus pabaigoje tarp naudojamų vario lydinių atsiranda ị žalvarị panašių lydinių $(5: 13,14$; 4 pav. 2, 3 lent.). Tačiau pagrindinis vario lydinių sudèties pokytis įvyko virsmo iš ankstyvojo geležies amžiaus i ankstyvajji roméniškajj laikotarpi metu. Ankstyvojo geležies amžiaus pabaigoje, be liejimo, pagausèja dirbinių iš kaltos vielos ir plonų skardos lakštų. Technologiškai žalvaris buvo tinkamiausias dirbinių gamybai kalimo būdu. Taigi, vario lydinių elementinès sudèties pasikeitimas galejo atsirasti dèl didesnès Rytų Baltijos regiono dirbinių ịvairovès ankstyvojo geležies amžiaus pabaigoje. Kita vertus, elementinès sudèties lydinių kaita iš bronzos tipo lydinių í žalvarị buvo europiné tendencija, gana greitai pasiekusi Šiaurès rytų Europą. Lydiniai ar / ir metalo laužas dabartinę Lietuvos teritoriją pasiekdavo sudetinga ir ilga mainų grandine, naudojant skirtingus mainų ekvivalentus. Vario lydinių elementinè sudètis ankstyvuoju metalų laikotarpiu ir ankstyvuoju romėniškuoju laikotarpiu kito tuo pačiu ritmu, kokiu ji kito Europoje, ịsisavinant naujus rūdynus ir metalo laužą naujiems dirbiniams gaminti. Lietuvoje vario lydinių elementinès sudèties kaitos i žalvarị procesas ankstyvuoju romėniškuoju laikotarpiu buvo lydimas staigios aukštų gamybos technologijų plètros. Atsirado dirbinių, gamintų naudojant itin sudètingas gamybos ir apdirbimo technologijas $(6 ; 7 ; 8: 2-5$; 